Atmos. Chem. Phys., 18, 13755-13771, 2018

https://doi.org/10.5194/acp-18-13755-2018

(C) Author(s) 2018. This work is distributed under

the Creative Commons Attribution 4.0 License.

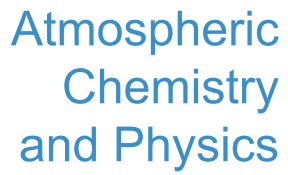

(c) (P)

\title{
Agricultural harvesting emissions of ice-nucleating particles
}

\author{
Kaitlyn J. Suski ${ }^{1}$, , Tom C. J. Hill ${ }^{1}$, Ezra J. T. Levin ${ }^{1}$, Anna Miller ${ }^{2}$, Paul J. DeMott ${ }^{1}$, and Sonia M. Kreidenweis ${ }^{1}$ \\ ${ }^{1}$ Department of Atmospheric Science, Colorado State University, Fort Collins, CO 80523, USA \\ ${ }^{2}$ Reed College, Portland, OR 97202, USA \\ anow at: Pacific Northwest National Laboratory, Richland, WA 99354, USA
}

Correspondence: Kaitlyn J. Suski (kaitlyn.suski@pnnl.gov)

Received: 2 April 2018 - Discussion started: 2 May 2018

Revised: 21 August 2018 - Accepted: 24 August 2018 - Published: 28 September 2018

\begin{abstract}
Agricultural activities can modify natural ecosystems and change the nature of the aerosols emitted from those landscapes. The harvesting of crops can loft plant fragments and soil dust into the atmosphere that can travel long distances and interact with clouds far from their sources. In this way harvesting may contribute substantially to icenucleating particle (INP) concentrations, especially in regions where agriculture makes up a large percentage of land use. However, a full characterization of particles emitted during harvesting has not been reported. This study characterizes immersion mode INPs emitted during harvesting of several crops in the High Plains region of the United States. The Colorado State University Continuous Flow Diffusion Chamber (CFDC) and the Ice Spectrometer (IS) were utilized to measure INP concentrations during active harvesting of four crops in Kansas and Wyoming. Large spikes of INPs were observed during harvesting, with concentrations over $200 \mathrm{~L}^{-1}$ at $-30^{\circ} \mathrm{C}$ measured during a wheat harvest. To differentiate between mineral and organic components, a novel heating tube method was employed in real time upstream of the CFDC to deactivate organic INPs in situ. The results indicate that harvesting produces a complex mixture of organic, soil dust, and mineral components that varies for different crops. Electron microscopy analysis showed that while mineral components made up a large proportion of INPs, organic components comprised over $40 \%$ of measured INPs for certain crops at warm temperatures. Heating and enzyme posttreatment of aerosol samples collected for IS processing indicated that bacteria and heat-labile and heat-stable organics contributed to wheat harvest-produced INPs. These results indicate that plant material and organic particles are a significant component of harvest INPs and their impacts on ice formation in clouds and precipitation on a regional scale should be explored.
\end{abstract}

\section{Introduction}

Currently, the accuracy of climate change predictions is limited by large uncertainties associated with quantifying aerosol-cloud interactions (IPCC, 2013). One step toward narrowing these uncertainties is identifying and quantifying key sources of aerosol particles that can aid in the formation of ice crystals in clouds, termed ice-nucleating particles (INPs). INPs are rare in the atmosphere (DeMott et al., 2010), and their sources are not well characterized or quantified. Some INP sources have been identified including mineral dust (DeMott et al., 2003), lofted biological particles (Pratt et al., 2009; Creamean et al., 2013), biomass burning aerosol (McCluskey et al., 2014; Prenni et al., 2012), sea spray (DeMott et al., 2016; Wilson et al., 2015), decaying leaf litter (Conen et al., 2016; Schnell and Vali, 1976), macromolecules on pollen (Pummer et al., 2012), and certain strains of fungi (Fröhlich-Nowoisky et al., 2015; O'Sullivan et al., 2016; Morris et al., 2013). Additionally, changes in emission rates of INPs have been correlated with rain events (Huffman et al., 2013; Prenni et al., 2013) and high relative humidity (Wright et al., 2014). Recently, soil dust and its ice nucleation potential have gained attention (Conen et al., 2011; Tobo et al., 2014; O'Sullivan et al., 2014; Hill et al., 2016). Soil dust contains both mineral and organic components, and it has been suggested that the organic and biological fractions of soil dust are responsible for a majority of its ice nucleation ability (Tobo et al., 2014; Conen et al., 2011; O'Sullivan et al., 2014; Hill et al., 2016). A variety of organic sources of INPs in soils including bacteria, fungi, and other soil organic matter classes have been identified (Hill et al., 2016); however, a thorough understanding and quantification of INPs from soil organic matter is lacking. 
Table 1. Sampling locations, elevations, and dates (given in $\mathrm{mm} / \mathrm{dd} / \mathrm{yy}$ ) for all of the harvests are given.

\begin{tabular}{llrrr}
\hline Sample & Location & Latitude, longitude & Elevation $(\mathrm{m})$ & Sampling date \\
\hline Pre-soybean harvest & Colby, KS & $39.394,-101.066$ & 966 & $10 / 14 / 14$ \\
Soybean & Colby, KS & $39.394,-101.066$ & 966 & $10 / 14 / 14$ \\
Sorghum & Colby, KS & $39.394,-101.066$ & 966 & $10 / 15 / 14$ \\
Wheat 1 & Colby, KS & $39.394,-101.066$ & 966 & $06 / 30 / 15$ \\
Wheat 2 & Colby, KS & $39.394,-101.066$ & 966 & $07 / 01 / 15$ \\
Corn & Lingle, WY & $42.126,-104.403$ & 1309 & $11 / 09 / 15$ \\
\hline
\end{tabular}

Aside from soils, plant fragments pulverized during harvesting and biological particles released from the surface of plants can serve as INPs. For instance, large numbers of icenucleating (IN) bacteria have been measured on leaf surfaces (Hill et al., 2014; Georgakopoulos and Sands, 1992), and elevated levels of INPs were observed during active harvesting of a corn field, some of which were identified as icenucleating bacteria (Garcia et al., 2012). Harvesting can loft these biological particles into the air (Lighthart, 1984), and once lofted they can travel long distances (Aylor, 1986; Nagarajan and Singh, 1990). Thus, harvesting can be a large daily and seasonal emission source of biological particles and INPs that could have regional impacts on precipitation.

Arable land makes up roughly $11 \%$ of land surfaces on Earth (FAO, 2010), and in the central United States the majority of land is used for agriculture. Characterizing the sources of INPs in such intensively disturbed land is, thus, essential to accurately predicting their role in cloud development and precipitation events over agricultural regions. Data presented here were collected during harvesting of four crops in the US High Plains over 2 years at agricultural research centers in Kansas and Wyoming. This work builds upon previous studies of harvest emissions by also utilizing pre- and post-treatments of the samples and electron microscopy to investigate the various mineral, organic, and biological components that contribute to the ice-nucleating ability of harvest emissions.

\section{Methods}

\subsection{Harvest sampling description}

Measurements were made at the Kansas State University Northwest Research-Extension Center in Colby, KS, and at the University of Wyoming Sustainable Agriculture Research and Extension Center (SAREC) in Lingle, WY. Harvests of soybean, sorghum, and wheat were sampled in Kansas, and a corn harvest was sampled in Wyoming. Photographs of the fields pre-, during, and post-harvest are shown in Figs. S1 and S2 in the Supplement. The harvests usually lasted $2-4 \mathrm{~h}$. Details of the sampling locations and dates are listed in Table 1. A mobile laboratory and gasolinepowered generators were used to sample in the fields during the harvests. Generators were always positioned downwind of the mobile laboratory. Additionally, the mobile laboratory was positioned downwind from the field being harvested and was repositioned if the plume was no longer reaching the laboratory due to a shift in wind direction or position of the combine harvester. Figure S3 shows an example GPS track of a combine harvester during a corn harvest and the mobile laboratory position in relation to the combine. Aerosols were sampled through an inlet comprised of a stainless-steel rain hat located $3.5 \mathrm{~m}$ above the ground with a $1 / 2 \mathrm{in}$. OD stainless-steel tube attached. From this tube, y-splitters were used to split the aerosol flow among various instruments. A schematic of the various sampling configurations used during the study is provided in Fig. S4 in the Supplement.

\subsection{Aerosol instrumentation}

Ice-nucleating particle concentrations were measured online with the Colorado State University (CSU) Continuous Flow Diffusion Chamber (CFDC) (Rogers et al., 2001; Eidhammer et al., 2010). Aerosols are introduced into the CFDC chamber, which has two cylindrical walls that are coated with ice and held at different temperatures. The temperature difference results in a supersaturation gradient that permits calculation of the supersaturation and temperature at the predicted position of the aerosol lamina ring within a particlefree sheath flow between the walls. For the measurements performed here, the CFDC was operated at $5 \%$ supersaturation with respect to water over a temperature range of -15 to $-32^{\circ} \mathrm{C}$. As discussed in DeMott et al. (2015), supersaturation uncertainty ranges from $<1.6$ to $>2.4 \%$ over this range of temperatures. While these settings potentially permit deposition, immersion, and condensation-freezing modes of ice nucleation to occur, conditions in the supersaturated (or growth) region of the CFDC emphasize aerosols growing into water droplets via condensation and then droplets that contain INPs freezing into ice crystals. Hence, data collected during operation in this manner are often compared to methods that explicitly examine immersion-freezing nucleation. Downstream of the growth region, droplet evaporation is stimulated (evaporation region) by holding the two iced walls at the same temperature to create water subsaturated conditions. This design feature amplifies the size difference between larger ice crystals and smaller aerosol particles. All 
particles are sized and counted by an optical particle counter (OPC, Climet CI-3100), and particles larger than $3 \mu \mathrm{m}$ are counted as ice crystals. A $2.4 \mu \mathrm{m}$ impactor $(50 \%$ aerodynamic cut-size diameter) was used upstream of the CFDC inlet to limit the size of particles entering the CFDC, as large particles $(>3 \mu \mathrm{m})$ would otherwise interfere with counting the ice crystals that form in the instrument. The uncertainty in INP concentration is calculated by adding in quadrature the Poisson counting-statistics-derived standard deviations of the sample and background periods, which are measured by sampling through a particle filter upstream of the CFDC (Schill et al., 2016). A statistical significance test is also performed on the data. If INP concentrations are greater than the error in INPs multiplied by 1.64 (INP > $\left(\mathrm{INP}_{\text {Error }} \cdot 1.64\right)$ ), which corresponds to the $\mathrm{Z}$ statistic at $95 \%$ confidence, then the data are considered statistically significant (Schill et al., 2016).

For select sampling periods, particles that formed ice in the CFDC were collected for chemical analysis via impaction onto electron microscopy (EM) grids (SPI Supplies Coated Grids Formvar ${ }^{\circledR} /$ Carbon, 200 mesh, nickel) with a $2.9 \mu \mathrm{m}$ single-stage inertial impactor (Kreidenweis et al., 1998). Scanning electron microscopy (SEM; Quanta FEG MK2) was used to image the particles, and energy dispersive Xray (EDX; Oxford Instruments X-Max EDS detector) analysis was performed to obtain elemental composition. Analysis was completed at the University of Wyoming Materials Characterization Laboratory. Analysis was done by analyzing individual particles on the filters (73 particles for the sorghum sample and 67 and 72 particles for the corn samples). Characteristic combinations of elements were identified and then used to group the individual particles into classes. Particles containing at least one mineral dust marker, such as silicon, aluminum, or iron, were labeled as dust particles. These particles typically contained oxygen and sometimes carbon as well. Particles with oxygen, carbon, and either sulfur or nitrogen were labeled as organic. If particles contained phosphorous, along with organic markers $(\mathrm{O}, \mathrm{C}, \mathrm{N}$ or $\mathrm{S})$, they were labeled as biological (Pratt et al., 2009). Mixtures of these particle types were labeled as both types. For example, if a particle contained silicon, carbon, oxygen, and nitrogen, it was labeled as dust-organic.

The CFDC sample flow rate of $1.5 \mathrm{~L} \mathrm{~min}^{-1}$ sets a limit of detection that restricts its useful temperature range for assessing INP number concentrations. This detection limit is also dependent on the background concentration measured. For the $10 \mathrm{~min}$ integrated sampling periods typically used and when background counts are low, this detection limit is $\sim 0.2 \mathrm{~L}^{-1}$. To help overcome this limitation, an aerosol concentrator (MSP 4240) was used upstream of the CFDC to concentrate aerosol using virtual impaction (Fig. S4b in the Supplement) (Romay et al., 2002). The concentrator was located on a cart $1 \mathrm{~m}$ above the ground. This method has been used in previous studies (e.g., Tobo et al., 2013). Measurements were taken for $10 \mathrm{~min}$ with and $10 \mathrm{~min}$ without the concentrator. A concentration factor (CF) was calculated by taking the number concentration of INPs during concentrated periods divided by the INP concentration during temporally adjacent non-concentrated periods. During harvesting, there were large spikes in concentration due to the passing of a combine harvester. This made CF calculations difficult when the concentrated and non-concentrated INP values were not equally affected by the spikes. It was important to use a time period within the overall harvesting experimental period that included stable aerosol concentrations during periods on and off the concentrator. Therefore, the CF calculated during a pre-soybean harvest period in Colby, $\mathrm{KS}(\mathrm{CF}=90 \pm 3)$, was used as the $\mathrm{CF}$ for all of the harvests. We may note that this value is within $15 \%$ of the value found by Tobo et al. (2013) in prior studies with the same aerosol concentrator and CFDC instrument. This is physically expected if most INPs reside in the size range above $0.5 \mathrm{~mm}$. CF uncertainty was calculated by propagating the uncertainties in the INP values used to calculate it. Then, the INP number concentrations during periods using the concentrator were corrected by dividing INP number concentrations by the CF.

The Ice Spectrometer (IS) immersion freezing method uses aerosols collected onto filters over periods of $2-4 \mathrm{~h}$, achieving 800-3500 L sample volumes that can extend the range of INP measurements to warmer temperatures and a detection limit of $\sim 0.001 \mathrm{INPs}^{-1}$. Although creating difficulties for comparing methods when higher-frequency changes in INP concentrations are occurring, these two methods are complementary, offering colder temperatures and higher time resolution with the CFDC and warmer temperatures and lower INP detection limits with the IS. For IS analysis, aerosols were collected onto $47 \mathrm{~mm}$ diameter, $0.2 \mu \mathrm{m}$ pore diameter (sometimes $0.05 \mu \mathrm{m}$ ) polycarbonate Nuclepore filters (Whatman, GE Healthcare Life Sciences) fitted within open-faced Nalgene sterile filter units (Thermo Fisher Scientific Inc.). During the wheat and corn harvests, a $2.5 \mu \mathrm{m}$ cyclone $(50 \%$ aerodynamic cut-size diameter at 16.7 $\mathrm{L} \mathrm{min}^{-1}$, URG Corporation) was also used, upstream of a $47 \mathrm{~mm}$ diameter inline aluminum filter holder (Pall Corporation) fitted with a $0.2 \mu \mathrm{m}$ diameter pore Nuclepore membrane. This limited the size of the particles collected to the same size range as the CFDC. Filters and dissembled filter holders were cleaned before use by immersion in $10 \%$ $\mathrm{H}_{2} \mathrm{O}_{2}$ for $30 \mathrm{~min}$ followed by three rinses in deionized water ( $18 \mathrm{M} \Omega$ and $0.2 \mu \mathrm{m}$ pore diameter filtered) and then dried by removal of excess water and placement on foil in a clean-air laminar flow cabinet.

For processing in the laboratory, filters were transferred to sterile, $50 \mathrm{~mL}$ Falcon polypropylene tubes (Corning Life Sciences); $7-10 \mathrm{~mL}$ of $0.02 \mu \mathrm{m}$ pore diameter filtered water (Anotop syringe filter, Whatman) with $2 \mathrm{mM} \mathrm{KCl}$ was added to maintain activity of $\mathrm{K}$ feldspar, if present. Prior tests on dilute suspensions of pure $\mathrm{K}$ feldspar found that the use of deionized water reduced IN activity, presumably due to desorption of $\mathrm{K}^{+}$; the use of a suspension containing $\geq 0.1 \mathrm{mM} \mathrm{K}^{+}$prevented this and so was used for dilutions. 
Tubes were tumbled end-over-end at 1 cycle s$^{-1}$ for $20 \mathrm{~min}$ (Roto-Torque, Cole-Palmer) to resuspend particles. Measurements of immersion freezing were made on this suspension and 20-, 400- and 8000-fold dilutions of it. Thirty-two $50 \mu \mathrm{L}$ aliquots of each dilution and a negative control $(2 \mathrm{mM} \mathrm{KCl})$ were then dispensed into two 96-well polymerase chain reaction (PCR) trays ( $\mu$ Cycler, Life Science Products), which were then transferred to the cold blocks in the IS. The trays were then slowly cooled by lowering the temperature at a rate of $0.3^{\circ} \mathrm{C} \mathrm{min}^{-1}$ from 0 to $-27^{\circ} \mathrm{C}$, and the numbers of wells frozen were counted at 0.5 or $1{ }^{\circ} \mathrm{C}$ intervals. Cumulative numbers of INPs per volume of liquid as a function of temperature were estimated using the formula $-\ln f_{u}(T) / V$, where $f_{u}(T)$ is the proportion of droplets not frozen at a given temperature and $V$ is an aliquot volume (Vali, 1971). Values were then converted to concentrations per liter air samples. Uncertainties are given as binomial sampling confidence intervals (95\%) (formula no. 2, Agresti and Coull, 1998). For a detailed description of the IS, see Hiranuma et al. (2015).

Ambient aerosols were sized at aerodynamic sizes larger than $0.542 \mu \mathrm{m}$ using an aerodynamic particle sizer (APS; TSI 3321) and counted using a condensation particle counter (CPC; TSI 3010). The wideband integrated bioaerosol sensor (Droplet Measurement Technologies WIBS-4A) was used to collect information on fluorescent and biological aerosols. The WIBS-4A, from here onward referred to as the WIBS, gives fluorescence information in three channels: FL1 (fluorescence at $310-400 \mathrm{~nm}$, excited at $280 \mathrm{~nm}$ ), FL2 (fluorescence at $420-650 \mathrm{~nm}$, excited at $280 \mathrm{~nm}$ ), and FL3 (fluorescence at $420-650 \mathrm{~nm}$, excited at $370 \mathrm{~nm}$ ). Particles from 0.8 to $20 \mu \mathrm{m}$ are sized by light scattering. Based on fluorescence signatures, the data were classified into four particle classes: any particles measured with the WIBS (total particles), particles that fluoresced in at least one channel (FP), particles that fluoresced in two channels (termed fluorescent biological aerosol particles, FBAPs), and particles that fluoresced strongly in channel FL1 and weakly or not at all in channels FL2 and FL3 (FP3), as described in Wright et al. (2014). The WIBS instrument was non-functional during the corn harvest on 9 November 2015; thus, fluorescence data supplied for corn are from a corn harvest on a different day (4 November 2015) but at the same field in Wyoming.

\subsection{Pre- and post-treatments}

This work utilized two different types of treatments to tease out the various biological and chemical compositional influences on INPs measured in the ambient environment. Upstream of the CFDC, a tube heated to $300^{\circ} \mathrm{C}$ was used to deactivate organic components before they entered the CFDC. The heating tube setup, shown in Fig. S4c in the Supplement, consists of two tube furnaces (Thermolyne 21100) placed next to each other in series with a 1 in. diameter quartz tube running through the center of the tube furnaces. By measur- ing INP concentrations with and without passage through the heating tube, the fraction of organic INPs, which are deactivated by heating, can be measured in situ. Previously, heat and peroxide have been used to degrade organic INP components in bulk soil samples and aerosol generated from it post treatment (Tobo et al., 2014; Hill et al., 2016). While useful, these methods do not provide precise time resolution on single particles, which is important for episodic events. Thus, to enable higher time resolution of single ambient particles, an online heating technique was developed and used in this work. For initial optimization, to ensure that the heating tube method was comparable to the previous bulk heating results, the same soil sample (soil from a sugar beet crop collected in Wyoming) used by Tobo et al. (2014) in the bulk heating analysis was aerosolized and run with the heating tube setup. The previous study measured aerosolized pre-treated soil particles size-selected at $0.6 \mu \mathrm{m}$ using a differential mobility analyzer (DMA; TSI 3080) before sampling with the CFDC. In this study, particles are size-selected at $0.5 \mu \mathrm{m}$. However, this difference in size did not greatly change the results. Figure S5 in the Supplement shows the previous results using the bulk heating method (Tobo et al., 2014) plotted with the results using the heating tube. Data from the heating tube at $300^{\circ} \mathrm{C}$ agree well with results from the bulk heating experiment. This comparison demonstrates that, even though particles only pass through the heating tube for $98 \mathrm{~s}$ with a flow rate of $1.5 \mathrm{~L} \mathrm{~min}^{-1}$, the heating tube technique is as effective at degrading organic components as the bulk heating method, which entailed heating to $300^{\circ} \mathrm{C}$ in an oven for $2 \mathrm{~h}$.

Post-treatments were also applied to the IS filter wash water of the wheat harvest sample to selectively deactivate different INP components. To denature labile organic components (e.g., proteins), an aliquot was heated to $95^{\circ} \mathrm{C}$ for $20 \mathrm{~min}$, while to decompose and remove all organic INPs, an aliquot of the wash water was digested with hydrogen peroxide. The latter used the same method as detailed in McCluskey et al. (2018), except we used a more powerful UV source for hydroxyl radical generation. Briefly, this entailed adding $30 \% \mathrm{H}_{2} \mathrm{O}_{2}$ (Sigma Aldrich) to the aliquot to achieve a final concentration of $10 \%$ and then immersing the suspension in water heated to $95^{\circ} \mathrm{C}$ for 20 min while being illuminated with two $26 \mathrm{~W}$ UVB fluorescent bulbs (Exo Terra) to generate hydroxyl radicals. To remove residual $\mathrm{H}_{2} \mathrm{O}_{2}$, catalase (cat. number 100429, MP Biomedicals) was added in $20 \mu \mathrm{L}$ aliquots to the cooled solution, allowing several minutes between each addition, until no further effervescence occurred. To lyse all bacteria (including known IN species) another aliquot was incubated with lysozyme to digest their cell walls (lysozyme also hydrolyzes fungal chitin oligosaccharides but not the chitin polymer itself). An aliquot of the aerosol suspension was amended to contain $4 \mathrm{mg} \mathrm{mL}^{-1}$ lysozyme, $10 \mathrm{mM}$ Tris buffer, and $5 \mathrm{mM}$ EDTA (both at $\mathrm{pH} 8$ ) and incubated at $24^{\circ} \mathrm{C}$ for $3 \mathrm{~h}$. For a detailed description of this method, see Hill et al. (2016). 
Table 2. WIBS data collected during the harvests showing the percentages and concentrations of fluorescent particles (FP), particles that fluoresce in channel 1 (FP3), and fluorescent biological aerosol particles that fluoresce in two channels (FBAPs). INP concentrations measured with the IS with (bold) and without (normal) a cyclone are presented at $-15,-20$, and $-25^{\circ} \mathrm{C}$.

\begin{tabular}{lrrrrrrrrr}
\hline Sample & $\begin{array}{r}\text { FP } \\
\%\end{array}$ & $\begin{array}{r}\text { FP3 } \\
\%\end{array}$ & $\begin{array}{r}\text { FBAP } \\
\%\end{array}$ & $\begin{array}{r}\text { FP } \\
\left(\mathrm{L}^{-1}\right)\end{array}$ & $\begin{array}{r}\text { FP3 } \\
\left(\mathrm{L}^{-1}\right)\end{array}$ & $\begin{array}{r}\text { FBAP } \\
\left(\mathrm{L}^{-1}\right)\end{array}$ & $\begin{array}{r}\mathrm{INP}-15^{\circ} \mathrm{C} \\
\left(\mathrm{L}^{-1}\right)\end{array}$ & $\begin{array}{r}\mathrm{INP}-20^{\circ} \mathrm{C} \\
\left(\mathrm{L}^{-1}\right)\end{array}$ & $\begin{array}{r}\mathrm{INP}-25^{\circ} \mathrm{C} \\
\left(\mathrm{L}^{-1}\right)\end{array}$ \\
\hline Pre-soybean harvest & 85.7 & 3.6 & 6.8 & 128.6 & 5.4 & 10.2 & 0.08 & 1.6 & $* 100$ \\
Soybean & 81.2 & 4.9 & 17.8 & 156.9 & 9.5 & 34.4 & 0.26 & 3.0 & 180 \\
Sorghum & 88.5 & 2.6 & 11.8 & 348.5 & 10.1 & 46.6 & 0.51 & 3.5 & 180 \\
Wheat 1 & 90.5 & 11.1 & 0.7 & 1580.0 & 193.2 & 12.7 & $76 / \mathbf{3 . 1}$ & $180 / \mathbf{4 . 7}$ & $\mathbf{6 1 0}$ \\
Wheat 2 & 65.7 & 4.5 & 0.3 & 415.1 & 28.7 & 2.2 & $14 / \mathbf{0 . 2 2}$ & $33 / \mathbf{1 . 2}$ & $721 / \mathbf{9 1}$ \\
Corn & 88.8 & 17.8 & 33.5 & 285.3 & 57.2 & 107.7 & $2.7 / \mathbf{0 . 1 6}$ & $8.1 / \mathbf{0 . 3 3}$ & $200^{*} / \mathbf{2 9}$ \\
Pre-corn & & & & & & & 0.05 & 0.70 & 6.9 \\
\hline
\end{tabular}

* The pre-soybean harvest INP concentration is extrapolated from the limit of measures at $-24.5^{\circ} \mathrm{C}$ and the corn from $-23.5^{\circ} \mathrm{C}$.

\section{Results}

\subsection{Harvest INP emissions}

Measurements were made during a soybean harvest on 14 October 2014, a sorghum harvest on 15 October 2014, and during a wheat harvest (30 June and 1 July 2015, referred to as Wheat 1 and Wheat 2, respectively) in Colby, $\mathrm{KS}$, and during a corn harvest in Lingle, WY, on 9 November 2015. Figure 1 shows CFDC and IS INP number concentrations measured during the harvests. The corn and wheat IS data were sampled through a $2.5 \mu \mathrm{m}$ cyclone, in addition to open-faced Nalgene sterile filter units, to limit the size range of particles that were collected. While the use of the cyclone will not capture the IN activity of larger particles, these larger particles will sediment out faster than smaller particles and likely do not make it to cloud level. Therefore, the use of the cyclone and impactor offer a better representation of particles that could impact clouds. IS data with and without the cyclone are provided in Table 2 for a comparison of INP concentrations with and without larger particles.

The CFDC INP number concentrations are averaged over 3 to 5 min periods, and the IS INP number concentrations represent the average over the whole harvest sampling period (typically $2-4 \mathrm{~h}$ ). For a given CFDC operating temperature, there was a broad range of INP number concentrations for a given harvest due to the nature of harvest sampling: the concentrations vary rapidly in time due to the movement of the combine harvester up and down the field, laterally across, and closer and further away from the mobile laboratory and due to the stopping and starting of the harvesting. Thus, the difference in time resolution between the CFDC and IS techniques can explain some of the greater spread in CFDC data. Even so, the IS and CFDC data generally agree well in the overlap region between -15 and $-25^{\circ} \mathrm{C}$. INP concentrations ranged from 0.5 to $147 \mathrm{~L}^{-1}$ at $-30^{\circ} \mathrm{C}$ as measured with the CFDC, and the IS data showed a maximum INP concentration of $922 \mathrm{~L}^{-1}$ at $-25.5^{\circ} \mathrm{C}$ during the wheat harvest. In general, these concentrations are very high compared to back- ground INP concentrations and global averages (e.g., DeMott et al., 2010). This result was consistent with limited previous harvest sampling (Garcia et al., 2012) but not consistent when comparing crops harvested or even between harvests of the same crop (i.e., wheat). Further, measurements from a corn harvest in Nebraska described by Garcia et al. (2012) showed INP concentrations from drop freezing analysis between 30 and $80 \mathrm{~L}^{-1}$ at $-20^{\circ} \mathrm{C}$ and an average CFDC INP concentration of $5.9 \mathrm{~L}^{-1}$. In this study, average number concentrations of 8.1 and $3.6 \mathrm{~L}^{-1}$ were measured with the IS and CFDC, respectively, at this temperature. While the CFDC results agree quite well between the two studies, there was up to an order of magnitude difference between the immersion freezing measurements. The average distance from the combine harvester during sampling or differences in plant and soil properties at the time of harvesting could contribute to this. While the soil was dry during the Nebraska harvest, it was wetter during this study due to recent heavy rain, thus limiting the amount of soil dust kicked up during sampling. These results illustrate the complexity of harvest emissions due in part to varying concentrations in time, distance from the source, and soil moisture.

The shapes of all of the IS harvest spectra are similar, with a "hump" at the warm end $\left(-5\right.$ to $\left.-22^{\circ} \mathrm{C}\right)$, which is accentuated in wheat sample 1 . This warm temperature hump, which is a frequent feature in terrestrial INP spectra and is commonly observed in precipitation samples, is suggested to be from biological sources (Petters and Wright, 2015). Interestingly, the crop dust emissions from the wheat field were considered particularly strong due its infestation with rust (Marv Farmer, personal communication, 2015), a parasitic fungal infection. Rust breaks down plant cell walls, which can result in more and finer plant dust particles being produced during harvesting. Furthermore, rust damage to leaf tissues would have allowed many adventitious phylloplane bacteria and fungi to have flourished. IN bacteria have been measured on wheat at populations of $10^{8} \mathrm{~g}^{-1}$ of fresh green leaf in Wyoming (Hill et al., 2014) and at $3.5 \times 10^{6} \mathrm{~g}^{-1}$ of 



Figure 1. INP number concentrations divided by the concentration factor (CF) measured using the CFDC (squares) and IS (circles) during four harvests are shown as soybean (a), sorghum (b), wheat (c), and corn (d). The smaller squares represent particles sampled on the concentrator, while the larger squares are sampled without the concentrator. Both significant and non-significant data are shown. Panels (c) and (d) are data collected through a $2.5 \mu \mathrm{m}$ cyclone.

fresh dry leaf at harvest in Colorado (Garcia et al., 2012), and rust has been shown to be IN active at warm temperatures (Morris et al., 2013). Thus, these various biological particles could have contributed to the INP concentrations seen in the pronounced hump in the IS spectrum for this case. Also, total aerosol numbers, the concentration of fluorescent particles (see below), and INP concentrations on this day were the highest observed in all of the harvest measurements. This suggests that the direct and indirect consequences of the fungal infection of the wheat crop could be contributing to the large number of particles and could be altering the characteristics of the emitted particles.

It should be noted that the CFDC and IS INP spectra have different slopes and the concentrations can be quite different at colder temperatures. The CFDC INP concentrations are generally higher than or similar to the IS at warmer temperatures but lower at temperatures below $-25^{\circ} \mathrm{C}$. The reasons for this are not fully understood; however, there are some possible explanations, as discussed in DeMott et al. (2017) and revisited here. Particle conglomerates could break up while in the IS wash water, which could provide more INPs in the bulk solution than are present as single particles measured in the CFDC. Alternately, small ice-nucleating entities (INEs), such as protein complexes (Hartmann et al., 2013) or macromolecules on pollen (Augustin et al., 2013; Pummer et al., 2012), could be present on and then released from the particle surfaces, and these INEs might be especially active at lower temperatures. Size could also play a role, as INP sizes are generally larger during harvests (Mason et al., 2016) and are not as effectively sampled into the CFDC. During the soybean and sorghum harvests, no size restriction was placed on the IS filters; thus larger particles $(>2.5 \mu \mathrm{m})$ are underrepresented in the CFDC data as compared to the IS. This is less of a concern (and indeed may be reflected in the data) for the corn and wheat harvests because a $2.5 \mu \mathrm{m}$ cyclone was used to restrict particle sizes on 
the IS filters. Finally, there may be a time dependence of ice nucleation that accentuates differences between the CFDC and IS measurements at lower temperatures. Particles are in the CFDC growth region for approximately $5 \mathrm{~s}$, while they are at a particular temperature for several minutes in the IS. However, previous results suggest there is little temperature dependence to stochasticity (Wright and Petters, 2013), and thus it is unlikely that the time difference is the cause of the discrepancy that occurred at the lowest temperatures.

\subsection{Fluorescent particles}

Fluorescent and biological particle concentrations and types measured by the WIBS were grouped into particle classes as described in the "Methods" section. These data are shown in Fig. 2 and Table 2. Interestingly, FBAPs were observed before the start of the soybean harvest period, which has been termed the "pre-soybean harvest" period. During the soybean harvest, the FBAP percentage increased from $6.8 \%$ during the pre-soybean harvest period to $17.8 \%$, indicating that additional biological particles were emitted during the harvest. This pre-harvest period was likely strongly influenced by harvesting in the region even though we were not directly in a fresh harvest plume. The corn harvest produced the largest percentage and concentration of FBAPs out of all of the harvests sampled $\left(33.5 \%, 107.7 \mathrm{~L}^{-1}\right)$. These results suggest an abundance of biological particles are emitted during corn harvests, which is supported by a previous study that showed corn harvests emit bacteria (Garcia et al., 2012), and could also indicate that more plant fragments are emitted during corn harvests than for other plant harvests. While wheat harvests emitted the highest number of fluorescent particles, they had the lowest percentages of FBAPs and Wheat 2 had the lowest concentration of FBAPs $\left(2 \mathrm{~L}^{-1}\right)$. This indicates that the wheat emissions only fluoresced in one channel and could point to the greater presence of plant material or soil dust, as opposed to other biological particles. Lignin is present in wheat and absorbs at $280 \mathrm{~nm}$ and emits at $\sim 360 \mathrm{~nm}$, which would give a signal at FL1 (Albinsson et al., 1999). Wheat lignin also autofluoresces with excitation at $330-385 \mathrm{~nm}$ and detection at $420 \mathrm{~nm}$, so it will give a signal at FL3. Therefore, if wheat lignin made up a bulk of the emitted particles, they might show up as FBAPs; however, FBAPs made up a low percentage of particles. This suggests that the bulk of the fluorescent wheat particles lack lignin and could be non-lignified plant cells or dead microbes.

The FP3 particles did not make up a significant percentage of particles, except during the first wheat harvest and the corn harvest, and average concentrations ranged from $5 \mathrm{~L}^{-1}$ in the pre-soybean harvest period to $193 \mathrm{~L}^{-1}$ during the Wheat 1 harvest. These particles have not been biologically or chemically identified but have been shown to correlate with INP concentrations (Wright et al., 2014). FP3 is indicative of the presence of tryptophan and the absence of nicotinamide adenine dinucleotide + hydrogen $(\mathrm{NADH})$ and could indicate

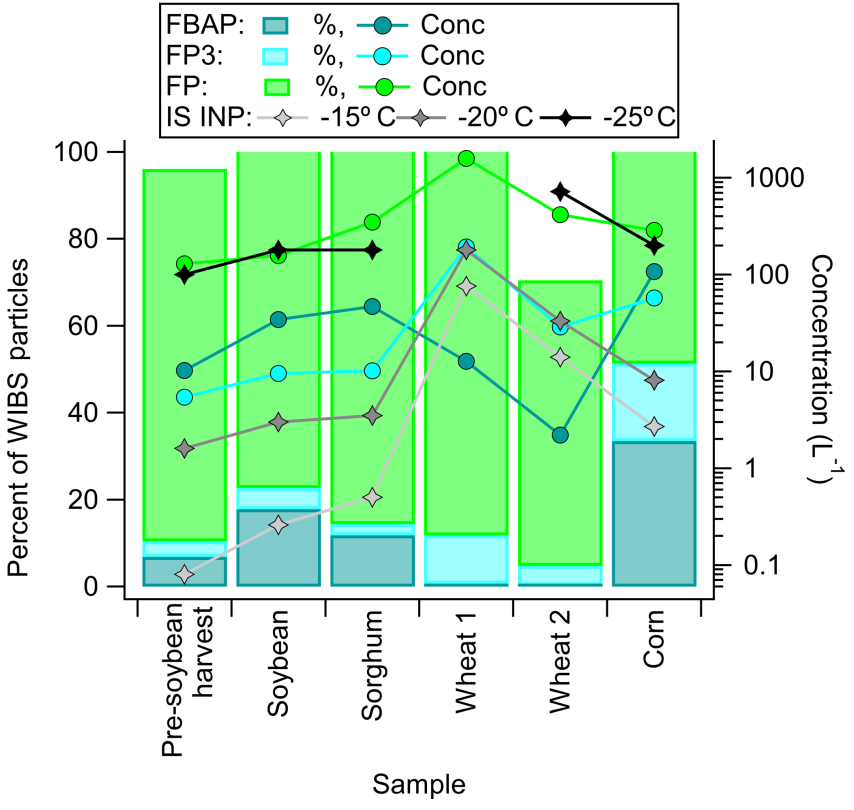

Figure 2. WIBS data showing the concentration (circle markers) and percentage (bars) of three different classes of fluorescent particles (FP, FP3, and FBAP) during each harvest and one pre-soybean harvest period. The corn WIBS data were collected from the same field but on a different day than the corn IS data. The IS INP concentrations for $-15^{\circ} \mathrm{C}$ (light grey), $-20^{\circ} \mathrm{C}$ (dark grey), and $-25^{\circ} \mathrm{C}$ (black) are shown in diamond markers for non-cyclone samples only.

dead plant and microbial material containing protein (e.g., dead phloem cells, dead bacteria, and fungi). Figure 2 and Table 2 also include IS INP concentrations at three temperatures for comparison to the fluorescent particle concentrations. In general, the INP concentrations measured without a cyclone at $-20^{\circ} \mathrm{C}$ are on the same order of magnitude as the FP3 concentrations, and thus FP3 concentrations show potential as an indicator of INP concentration at $-20^{\circ} \mathrm{C}$. The Wheat 1 case is somewhat of an outlier with the highest INP concentration at $-15^{\circ} \mathrm{C}$, which was on the same order of magnitude as the FP3 concentration. Overall, the best agreement was between the FP concentrations and the $-25^{\circ} \mathrm{C}$ INP concentrations, which agreed very well for the three samples that had IS data at $-25^{\circ} \mathrm{C}$.

\subsection{Chemical composition of INPs}

To chemically characterize the harvest INPs, particles were collected via impaction onto SEM grids downstream of the CFDC. During the sorghum harvest, mineral dust made up $41 \%$ of INPs at $-17^{\circ} \mathrm{C}$, as shown in Fig. 3a. Organic material also made up a large fraction $(29 \%)$ of the INPs along with mixtures of dust and organics $(13 \%)$ and a small percentage of purely biological particles $(2 \%)$. Images of the particles, shown in Fig. 3b, include interesting structures that 


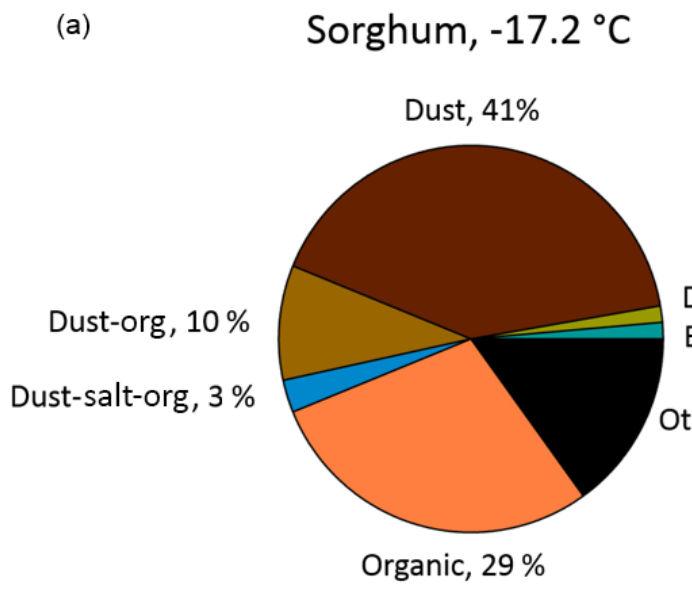

(b)

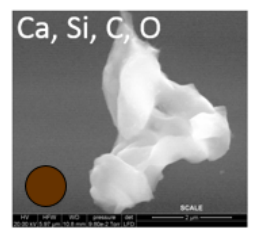

Dust-bio, $1 \%$

Bio, $1 \%$

Other, $15 \%$
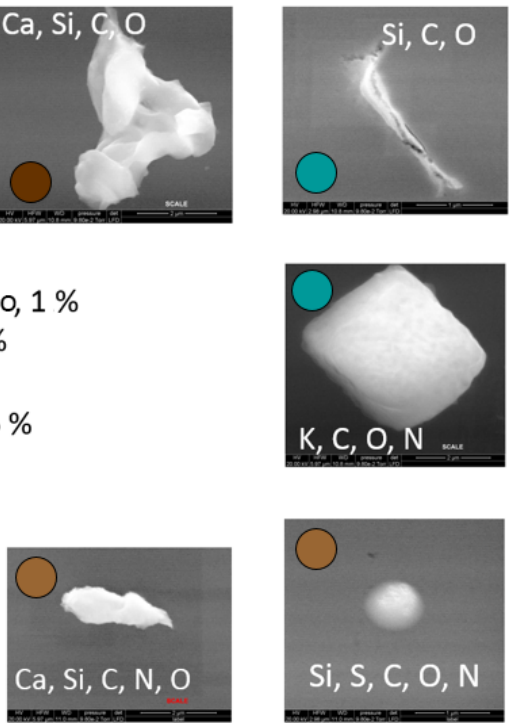

Figure 3. Relative amounts of different particle types collected via impaction and analyzed using SEM-EDX (a) and example SEM images with the corresponding elemental composition measured with EDX shown in white (b). The colored circle in the left corner of the images indicates which chemical class the particles were classified as. These data were collected during a sorghum harvest with a CFDC operating temperature of $-17^{\circ} \mathrm{C}$. In total, 73 particles were analyzed to make this pie chart.

could be indicative of plant material or biological particles. There were plate-like structures with potassium, thread-like filaments containing silicon, which could be plant material (Lux et al., 2002), and flaky structures with the elemental composition of mineral dust. These results indicate that organic components make up a large percentage of sorghum harvest INPs at $-17^{\circ} \mathrm{C}$.

SEM-EDX data from the corn harvest at $-27^{\circ} \mathrm{C}$, shown in Fig. 4a, indicate mineral dust again comprised a significant portion of INPs (32\%), along with dust mixtures with organics (Dust-org, 19\%), biological particles (Dust-bio, 13\%), and sulfate (Dust-S, 10\%). Additionally, there was a significant number of biological particles (18\%), which were identified by the presence of carbon, nitrogen, and phosphorous (Pratt et al., 2009). Many of the measured INPs also had structured forms similar to the sorghum harvest emissions. These particles had oblong, granular shapes and some appeared to have tiny hairs on the surface, suggesting they were of biological origin. The large percentage of biological INPs agrees well with previous measurements during corn harvests, which also showed the presence of several genera of bacteria among CFDC residuals (Garcia et al., 2012); this included $19 \mathrm{IN}$ bacteria $\mathrm{L}^{-1}$ air, quantified directly using quantitative PCR of the Ina gene. While SEM-EDX elemental compositions indicated the presence of biological particles, a full characterization of the biological components cannot be achieved with this method. Future work will utilize post-treatments of the filtered particles to further identify the types of biological particles that served as INPs. The WIBS data also revealed that the corn harvest produced the largest fraction and concentrations of FBAPs out of all the sampling locations. Taken together, these results indicate that organics and biological particles, along with mineral dust, make up a large percentage of harvest INPs between -17 and $-27^{\circ} \mathrm{C}$. SEM samples were not collected during the soybean and wheat harvests; therefore, a comparison of organic and mineral components cannot be directly assessed from these crops.

\subsection{Inferences regarding INP compositions through the use of heat and post-treatments}

In situ heating during real-time CFDC measurements was utilized to assess the contribution of minerals and organics to INPs emitted from harvests. Heating at $300^{\circ} \mathrm{C}$ has a similar impact on organics as peroxide digestion and will degrade heat-labile organics and biological particles (Tobo et al., 2014), and thus a comparison of heated and non-heated INP concentrations reveals the percentage of organic versus inorganic INPs. SEM-EDX results presented in Fig. 4b show the chemical changes in INPs that occurred with heating at $300^{\circ} \mathrm{C}$ during the corn harvest. The percentage of mineral dust increased, which is expected because, as organics are degraded with heating, minerals will remain IN active and make up a larger percentage of INPs. The percentage of biological INPs was reduced from $18 \%$ to $7 \%$, but they were not totally deactivated. The heat treatment dramatically reduced the percentage of Dust-bio INPs from $13 \%$ to $1 \%$, which suggests the IN-active biological components were degraded with heat, suggesting that the biological components played a larger role in the IN activity than the min- 
(a)

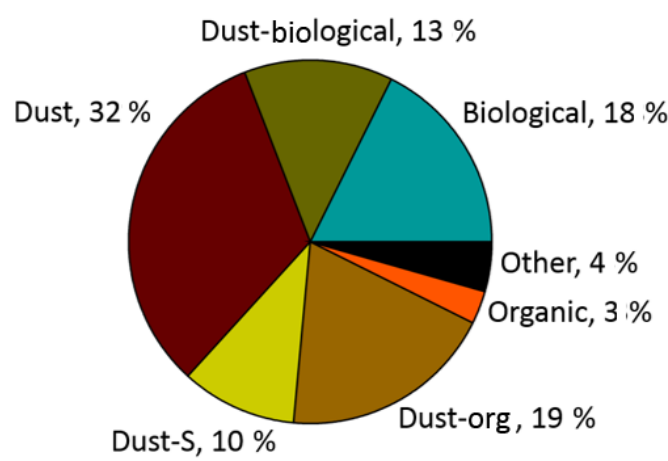

(c)

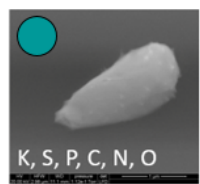

Corn, $-27^{\circ} \mathrm{C}$

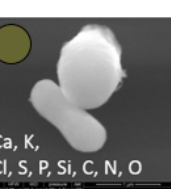

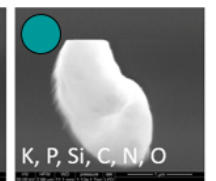

(b)

$$
\text { Corn, }-27^{\circ} \mathrm{C}+300^{\circ} \mathrm{C}
$$

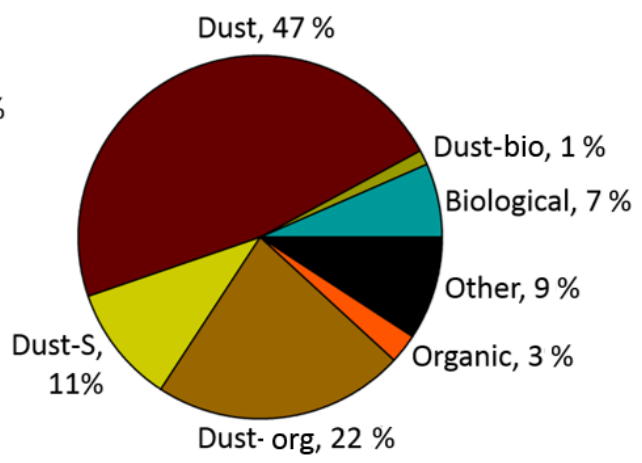

(d)

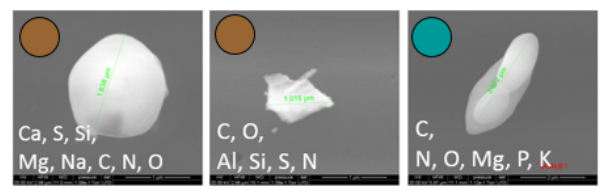

Figure 4. SEM-EDX data collected during a corn harvest. Panels (a) and (b) show relative amounts of each particle type as sampled using EDX, while (c) and (d) show example images of particles analyzed with SEM. The colored circle in the top left corner of the images indicates which chemical class the particles were classified as. Elemental composition is given in white on each of the example images. The data were collected at a CFDC operating temperature of $-27^{\circ} \mathrm{C}$ with the left-hand side (a, c) showing data without heat and the right-hand side (b, d) showing data for particles that had passed through a heating tube at $300^{\circ} \mathrm{C}$ upstream of the CFDC. Overall, 67 and 72 particles were analyzed to make the pie charts in (a) and (b), respectively.

erals within this class. The latter scenario is consistent with previous studies that show organic and protein residues on mineral surfaces can enhance the ice nucleation ability of the minerals (O'Sullivan et al., 2014, 2016; Conen et al., 2011). Interestingly, the percentage of Dust-org particles was not reduced with heating. This could indicate that the organics that were internally mixed with minerals were not susceptible to heat at $300^{\circ} \mathrm{C}$ or that, after the organics were degraded, the INP activity was unchanged because the minerals in these mixed particles were serving as the active sites for ice nucleation. Alternatively, heating the Dust-org particles could have evaporated off some volatile organics uncovering active sites on the dust. This study cannot differentiate between those scenarios, but future studies should investigate the physical changes caused by heating, including how heating might change mixing state and surface morphology.

The quantitative changes to ice-nucleating ability with heating are shown in Fig. 5. The fraction of INPs with respect to the concentration of total particles larger than $0.5 \mu \mathrm{m}$, as measured with the CFDC OPC $\left(n_{0.5} \mu \mathrm{m}\right)$, is plotted on the $y$ axis. INP fraction is shown instead of INP concentration to allow for direct comparison between heated and non-heated sampling periods. This is because there were large changes in particle concentrations due to sampling in and out of the harvesting plume and changing wind directions, which complicate a direct concentration comparison. This figure displays only statistically significant data points, as determined with the significance test described in the "Methods" section, unless otherwise noted. Results indicate that heating had a large impact on INP number concentration for soybean harvest emissions as cold as $-25^{\circ} \mathrm{C}$. Similarly, for the sorghum harvest, INPs were reduced by heating to below detection levels at $-18^{\circ} \mathrm{C}$, but a smaller impact was noted at temperatures $\leq-22^{\circ} \mathrm{C}$. During the corn harvest, heating reduced the fraction of INPs at warm temperatures $\left(-19^{\circ} \mathrm{C}\right)$ to below the instrumental detection limits, but at colder temperatures $\left(-28^{\circ} \mathrm{C}\right)$ there was only a slight change in the fraction. A similar situation appears for the wheat harvest, although data were not collected for heating trials below $-22^{\circ} \mathrm{C}$. These results suggest a general, albeit variable, impact in which organic (including biological) particles from harvesting exert more influence at warmer temperatures, while at colder temperatures mineral dust components likely dominated the ice nucleation activity. Further characterization of the emissions is necessary to identify the nature of the organic particles, but these results suggest harvest emissions are distinct for different crops.

The observed decrease in INPs with heating is presented in a different way in Fig. 6. Fractional change in INPs is shown for each temperature and crop in cases where heating measurements were made. At temperatures between -17 and $-19^{\circ} \mathrm{C}$ (the warmest temperature accessible for comparison via CFDC data), all of the harvest samples had large decreases in INP activity with heating. The fractional changes 


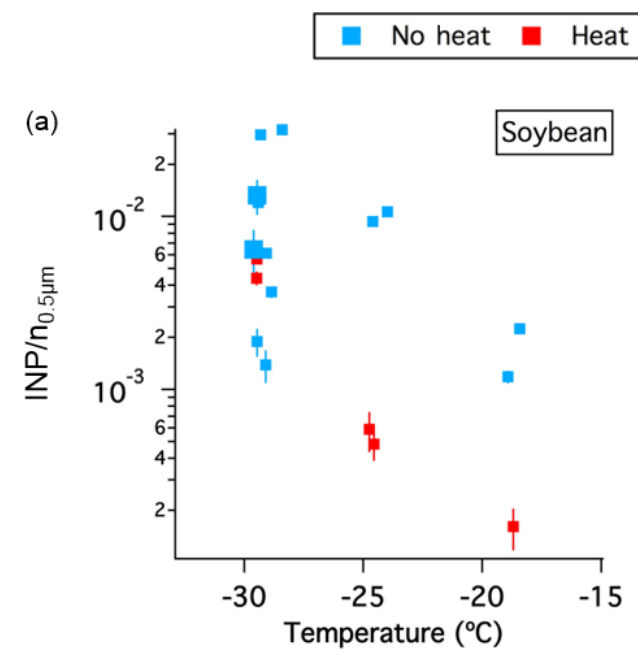

No concentrator - Concentrator
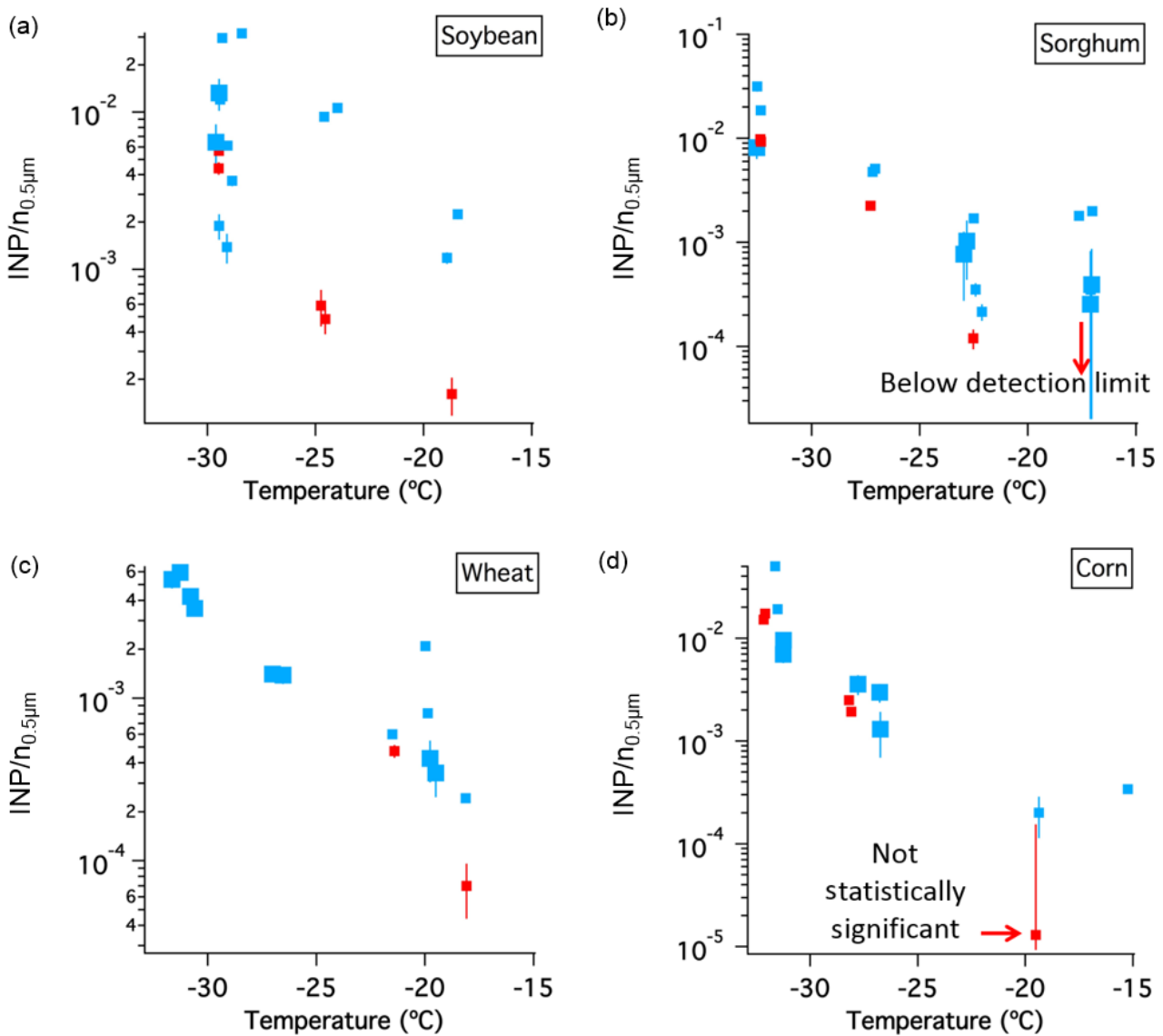

Figure 5. The fraction of INPs out of the total number of particles greater than $0.5 \mu \mathrm{m}$ as measured by the CFDC $\left(n_{0.5} \mu \mathrm{m}\right)$ is plotted against CFDC operating temperature for four crop harvests: soybean (a), sorghum (b), wheat (c), and corn (d). Data collected through the heating tube at $300^{\circ} \mathrm{C}$ are shown in red and non-heated data are in blue. The larger markers represent periods sampled without the concentrator, and the smaller markers represent periods sampled through the concentrator. Note the difference in scale on the $y$ axes.

at these relatively warm temperatures were between -0.7 and -0.98 , which suggests that a large percentage of these warm temperature INPs are of organic or biological origin. At $-32^{\circ} \mathrm{C}$, the INPs fractionally decreased by $\sim 0.5$ for all crops, indicating that minerals and possibly $300^{\circ} \mathrm{C}$ heatstable organics are contributing up to $50 \%$ of the INPs. However, the fact that there was still a reduction in INPs at these cold temperatures agrees with previous results that showed that organics contributed significantly to the INP population of soil dust even at cold temperatures where, traditionally, minerals are expected to dominate the activity (Tobo et al., 2014).

During the wheat harvest, heat treatment resulted in a $98 \%$ reduction in INP number concentrations at $-18^{\circ} \mathrm{C}$. This suggests that biogenic particles make up almost all of the INPs at temperatures $\geq-18^{\circ} \mathrm{C}$. Additional focus in the wheat sampling was placed on the evaluation of the contributions to this degradation observed in situ and in real time with the CFDC. Post-treatments on the wheat harvest sample via IS immer- sion freezing measurements, shown in Fig. 7, revealed a variety of biological/organic INP compositions contributing to the IN activity $>-20^{\circ} \mathrm{C}$, along with an underlying mineral or non-organic contribution to the IN activity, as suggested by the dashed grey line. Lysozyme digestion indicated that bacteria likely contributed foremost to the INP population. By digesting bacterial cell walls, lysozyme will cause rupturing of all bacteria. For the known species of ice nucleation active bacteria (e.g., Pseudomonas syringae, Pantoea agglomerans, and Xanthomonas campestris), clusters of the protein anchored in the outer membrane will, as the outer membrane disintegrates, disaggregate into smaller clusters active at $\sim-7$ to $-10^{\circ} \mathrm{C}$ or into single proteins active at -12 to $-13^{\circ} \mathrm{C}$ (Govindarajan and Lindow, 1988). However, in the wheat harvest sample the effect was observed as cold as $-21{ }^{\circ} \mathrm{C}$, suggesting that other, as yet unidentified, IN bacteria were not only present but abundant in the wheat dust. While WIBS data suggested that $<1 \%$ of particles were FBAPs, 

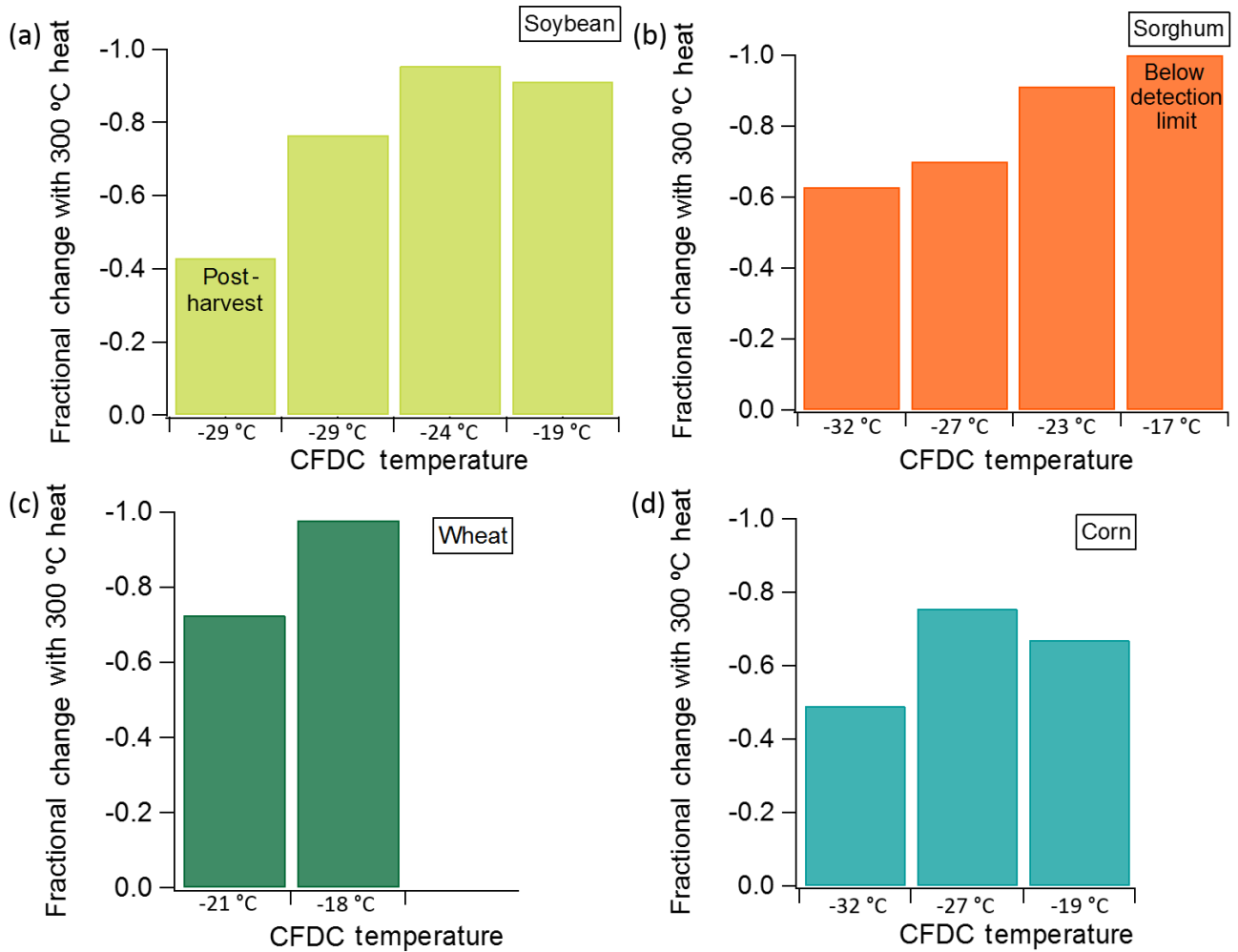

Figure 6. The fractional change in INP number concentrations due to heating at $300^{\circ} \mathrm{C}$ for four crop harvests for soybean (a), sorghum (b), wheat (c), and corn (d). The fractional change is shown for each CFDC operating temperature ( $x$ axis) where measurements were made. Heating was done in situ using a heating tube upstream of the CFDC.

the lysozyme digestion shows that a large amount of bacteria was generated from the harvest.

Bulk heating of the IS sample to $95^{\circ} \mathrm{C}$ resulted in a larger reduction of INPs that can be attributed to heat-labile INPs, such as proteins in bacteria and fungi, on the plants, and in soil dusts raised by the harvester. There was also a modest amount of organic material that was not susceptible to $95^{\circ} \mathrm{C}$ heat, but was degraded with peroxide digestion, that was contributing to INP concentrations and is evident in the shaded regions between the red markers and the black markers in Fig. 7. If arable soil dust contributed largely to the INP concentrations, peroxide treatment would show a greater reduction in INPs than was observed here. The large reduction due to heating indicates that biogenic particles make up a large percentage of INPs at temperatures warmer than $-18^{\circ} \mathrm{C}$. These biogenic particles come from a variety of sources, which highlights the complex nature of INPs emitted from agricultural and soil perturbation activities. No one particle type can accurately describe the nature of INPs for agricultural areas in general, but rather a mixture of biogenic particle types best represents these emissions. The findings in this study suggest that harvesting and plant litter emissions stimulated by wind at the surface provide the most viable explanation of the ubiquity of heat-labile INPs in the High
Plains boundary layer even in the absence of harvesting, as found by Garcia et al. (2012).

\subsection{Discussion and atmospheric implications}

Results presented herein, especially those shown in Figs. 6 and 7, emphasize the potential need to include harvesting INP emission impacts in regional cloud models to assess their subsequent impacts on clouds and precipitation in both agricultural and naturally vegetated regions. Harvesting emits mineral, organic, and biological particles into the atmosphere in large quantities. $\mathrm{PM}_{10}$ emission factors ranging from 10 to over $1000 \mathrm{~kg} \mathrm{~km}^{-2}$ have been reported for different crops harvested in California, and these emission factors vary based on crop, relative humidity, and soil moisture (Flocchini et al., 2001). A full characterization of the emitted organic matter is beyond the scope of this work and would involve intensive chemical, biological, and plant pathological investigations. Even from a single source such as harvesting, there are several distinct inputs including but not limited to pulverized plant tissues, dust, bacteria, fungi and other biological particles present on plant surfaces, various biological, organic and mineral INPs lofted from the soil, and even residual fertilizer on the soil surface. This complex combination of sources is difficult to untangle, especially because it can 


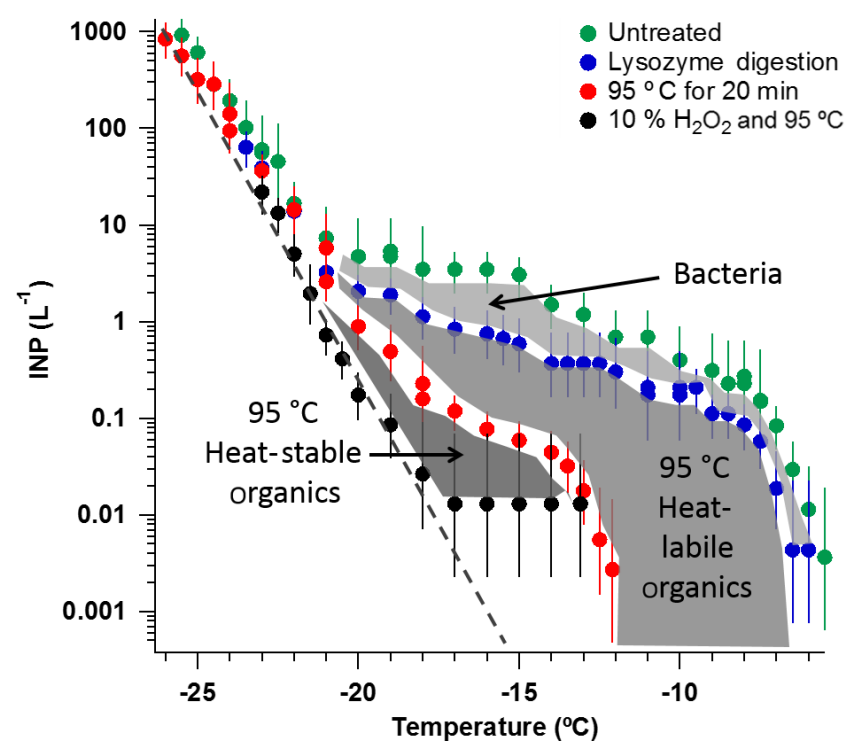

Figure 7. INP number concentrations resulting from a wheat harvest on 30 June 2015: measured by the IS (green); wash water treated with lysozyme to selectively remove bacterial INPs (blue); after heating to $95^{\circ} \mathrm{C}$ for $20 \mathrm{~min}$ (red); after peroxide digestion and heating to $95^{\circ} \mathrm{C}$ (black). The reduction in INP concentrations by removal of bacteria and heat-labile and heat-stable organics can be seen by the shaded areas. The dashed black line is representative of the likely underlying mineral INP spectrum.

change with geographic location, crop type, plant and soil states, environmental conditions during harvesting, and yearto-year differences in the many parameters. Additionally, different pathogens can grow on the crops, as was shown with the rust-infected wheat crop sampled in Colby, KS. All of these factors can change the ratio of mineral to organic components in the INPs, which has implications for how these emissions should be represented in models.

To assess the ability of existing INP parameterizations to model harvesting INP concentrations, the measured CFDC and IS INP number concentrations were compared to predicted INPs using parameterizations for average global INP concentrations (D10) (DeMott et al., 2010), mineral dust (D15) (DeMott et al., 2015), and biological particles (T13) (Tobo et al., 2013) (Fig. 8). The D10 and D15 parameterizations predict INP concentrations at a given temperature based on particle number concentrations above $0.5 \mu \mathrm{m}\left(n_{0.5 \mu \mathrm{m}}\right)$. For comparison with the IS, particle number ( $n_{0.5} \mu \mathrm{m}$ from the CFDC) was averaged over the IS sampling times. The D15 parameterization results presented here do not include the factor of 3 increase suggested in DeMott et al. (2015) for use in predicting atmospheric concentrations of relevance to clouds, because comparisons here are made to uncorrected CFDC and IS INP concentrations. The T13 parameterization uses biological particle concentrations, derived from the WIBS FBAP concentrations in this study, instead of $n_{0.5} \mu \mathrm{m}$ to predict INP concentrations. FBAP concen- trations were averaged over the CFDC and IS sampling times to compare to CFDC- and IS-derived INP concentrations, respectively. In applying WIBS FBAPs within the Tobo et al. (2013) parameterization, we must note that FBAP concentrations used to develop the parameterization were based on an ultraviolet aerodynamic particle sizer (UV-APS) that senses FBAPs at sizes above $0.5 \mu \mathrm{m}$, while the WIBS FBAP signal is for $>0.8 \mu \mathrm{m}$ particles. Hence, we expect that predicted values may be somewhat underestimated in this case. Note that all temperatures are integrated into such an analysis, so that biases may enter due to changes in the contributions of different compositions at different temperatures, as has been discussed. Also, the CFDC data presented here cover a narrower temperature range $\left(-17\right.$ to $\left.-32{ }^{\circ} \mathrm{C}\right)$ than that used in developing these parameterizations (e.g., -9 to $-34^{\circ} \mathrm{C}$ for D10).

Comparisons shown in Fig. 8 indicate that different crops have different relationships with CFDC-derived $n_{0.5 \mu \mathrm{m}}$ as described by different parameterizations. For instance, the corn CFDC and IS with cyclone INP data are predicted most accurately by the D15 parameterization. D15 is used to model dust INP activity; thus the correlation suggests that dust was serving as a source of INPs during the corn harvest. The SEM-EDX results presented in Fig. 4a confirm this and show that dust and dust mixtures made up $74 \%$ of INPs measured at $-27^{\circ} \mathrm{C}$. However, the IS data for all sizes (no cyclone) are predicted best with the D10 parameterization. The WIBS instrument was inoperable during the corn harvest; therefore, the T13 parameterization could not be tested against the corn data.

The first wheat harvest (Wheat 1) INP concentrations are predicted well with the D10 parameterization for CFDC and IS with cyclone data. This "global" INP parameterization represented a diverse range of INP sources (i.e., not distinct to one source), which may explain why it captures the diverse range of INPs that wheat harvests emit. Furthermore, this again supports the idea that elevated INP activity at temperatures higher than $-20^{\circ} \mathrm{C}$ observed in data compilations like DeMott et al. (2010) have their major sources from plant and microbial INPs. The cyclone-IS INP concentrations are predicted best by the D15 parameterization, although they are consistently overpredicted. The relationship between $n_{0.5 \mu \mathrm{m}}$ and CFDC INPs during the second wheat harvest, Wheat 2 , is not captured by any of the tested parameterizations. This could indicate changing emissions throughout the harvest or a mixture of minerals, organics, and biological particles that does not have a consistent relationship between $n_{0.5 \mu \mathrm{m}}$ or FBAPs and INPs. It might also suggest a nonfluorescing population or an especially active biological population not being represented by the T13 parameterization, which was modeled on data collected in a region rich in fungal spores and which might not capture the behavior of other biological types. To explore this scenario, the markers in Fig. 8 were colored by CFDC and IS operating temperature and are displayed in Fig. S6 in the Supplement. The Wheat 2 data 

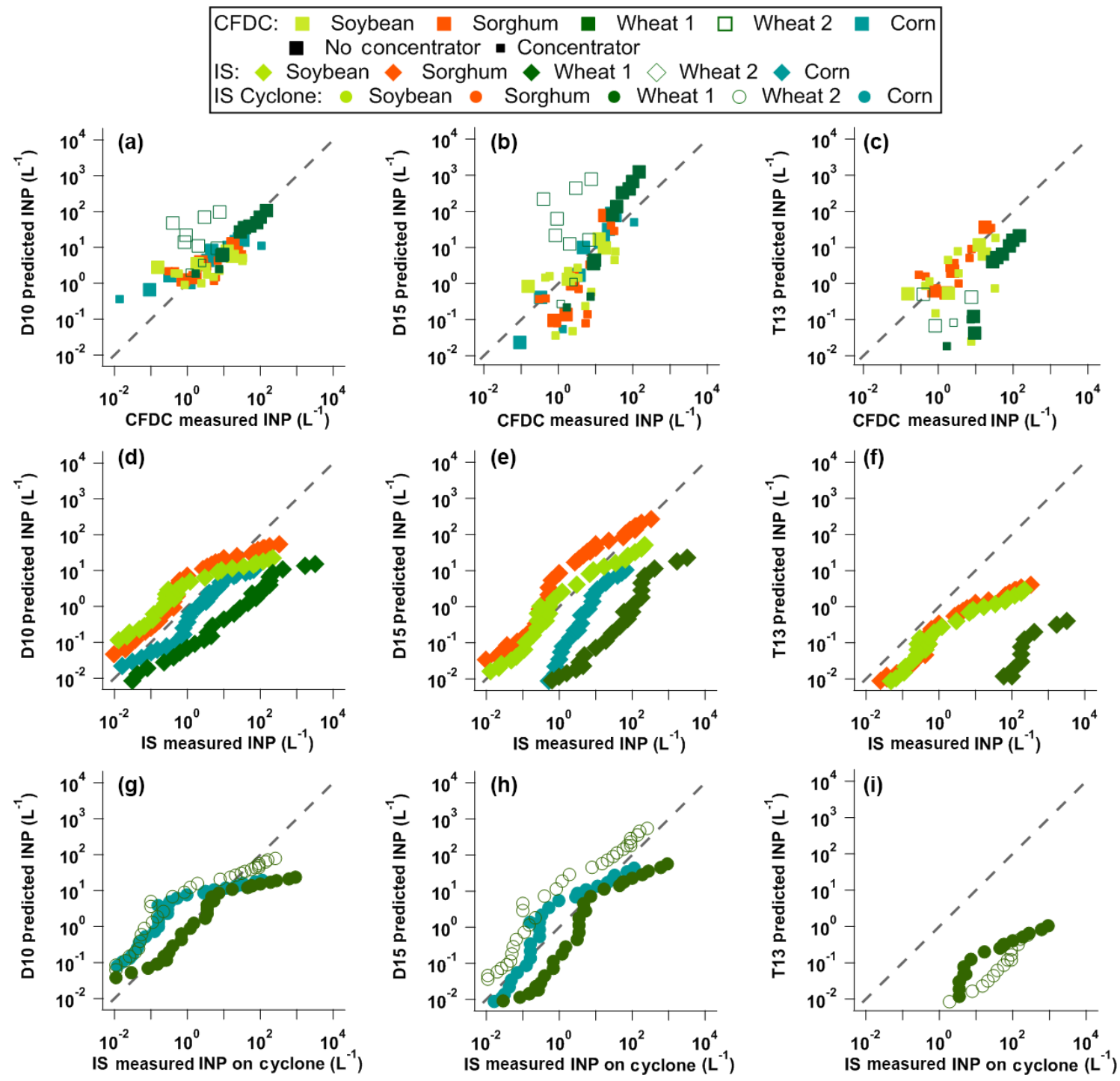

Figure 8. Measured CFDC (a-c), IS (d-f), and IS behind a $2.5 \mu \mathrm{m}$ cyclone (g-i). INP number concentrations plotted against predicted INP number concentrations using the D10 $(\mathbf{a}, \mathbf{d}, \mathbf{g}), \mathrm{D} 15(\mathbf{b}, \mathbf{e}, \mathbf{h})$, and T13 (c, f, i) parameterizations. The markers are colored by the different harvests; the size of the CFDC square markers indicates if the concentrator was used (smaller squares) or not (larger squares). The grey dashed line represents a $1: 1$ line for measured versus predicted INP.

points, as well as some Wheat 1 and soybean points that are not well predicted by $\mathrm{T} 13$, are mostly at warm temperatures (around $-20^{\circ} \mathrm{C}$ ). Thus, this could indicate a non-spore biological particle type was contributing to the INP population during these harvests.

The soybean harvest was modeled well by both the D10 and D15 parameterizations for both CFDC and non-cyclone IS data; however, the T13 parameterization also accurately predicted the CFDC data except for a few points. This might suggest that the soybean emissions had contributions to INPs from both dust and biological particles. The soybean emissions had a large percentage of FBAPs $(17.8 \%)$ according to the WIBS and a strong reduction in INP activity after heat treatment, which is indicative of biological INPs. However, the heat did not totally wipe out the IN activity, which suggests the presence of minerals in the INPs as well.

Sorghum CFDC INP concentrations are modeled well by both the D10 and T13 parameterizations, while the IS noncyclone data were best represented by D15. However, there is a hump in the data between -15 and $-18{ }^{\circ} \mathrm{C}$, which is better predicted by $\mathrm{T} 13$. This again suggests there is a mix of particle types including mineral dust and biological INPs present. Indeed, $\sim 11.8 \%$ of particles measured on the WIBS were FBAPs, and heating reduced the INP activity of the sorghum to below detection limit at $-17^{\circ} \mathrm{C}$ and by $63 \%$ at $-32^{\circ} \mathrm{C}$, indicating a strong organic contribution to INPs. 
SEM-EDX analysis of INPs active at $-17{ }^{\circ} \mathrm{C}$ shows $41 \%$ of INPs were mineral dust and, while a small fraction $(2 \%)$ of particles were of biological origin, a large percentage of INPs had organic components ( $42 \%$ ). Some of these organic particles could be from biological sources but based on their low (undetectable) levels of phosphorus, they were labeled as organic. Phosphorus is often a limiting nutrient in plants and is re-mobilized into living tissues or seeds when plants are senescing. The high organic but low biological signature could indicate that phosphorous was relocated from leaf and stem tissues to the sorghum grain before the harvest, which has been observed in sorghum when phosphorous is limited (Roy and Wright, 1974). Images of some of these particles (Fig. 3b) show structured shapes indicative of biological origin. This evidence points to the importance of organic and biological particles as well as mineral dust serving as INPs during the sorghum harvest.

The results presented here suggest that different crops have different relationships between aerosol number concentrations and INP concentrations. No single INP parameterization accurately predicts INPs released during harvest periods for all crops, but both D10 and D15 could be used in agricultural regions to predict ambient INP concentrations during harvest months, given measurements and/or forecasts of aerosol concentrations. FBAP concentration data are not readily available, and thus the comparison to the T13 parameterization is provisional at this point.

The large seasonal increases in harvest emissions could have effects on precipitation, especially in the Plains states where deep convection is frequently occurring. Several modeling studies have investigated the effects of increased aerosol concentrations on convection. One study showed that increases in aerosols modify storm structure but have minimal effects on warm-front precipitation (Igel et al., 2013), while another suggested deep convection in the Great Plains is modified by larger aerosol loading, by raising cloudtop height in mixed-phase clouds and by increasing precipitation rates in clouds with large amounts of liquid water $(\mathrm{Li}$ et al., 2011). Increases in biomass burning aerosols have been linked to increases in severe weather (Wang et al., 2009) and the likelihood of tornado formation (Saide et al., 2015), while mineral dust has been shown to have competing effects on squall lines with an overall weakening due to larger dust concentrations (Seigel et al., 2013). It is important to note that these studies have focused on the effects of aerosols serving as cloud condensation nuclei and have not included aerosols serving as INPs. The varying effects of aerosols on convection highlight the need to further investigate these scenarios and include INPs in these simulations, which could change the results and lead to a better representation of clouds and precipitation in agricultural regions in models.

\section{Conclusions}

Measurements made during the harvesting of four crops in the Great Plains indicate that highly complex mixtures of different organic particle types along with mineral components make up the spectrum of activity in harvest-derived INPs. SEM-EDX analysis confirms the presence of organic components in the harvest INP emissions as well as biological particles, mineral dust, and mixtures of these types. Highheat tests suggested contributions of both labile and stable organic INPs over the full temperature range measured, accounting for up to half of the INP activity even at $-30^{\circ} \mathrm{C}$ but dominating at temperatures above $-20^{\circ} \mathrm{C}$ for all crops. Soybean harvest emissions showed the largest contribution of organic components at colder temperatures $\left(-32^{\circ} \mathrm{C}\right)$, while corn harvests produced the largest fraction of biological particles in the total aerosol and showed a large fraction of biological INPs even at $-27^{\circ} \mathrm{C}$.

Organic particles, especially those of biogenic origin, contribute substantially to the ice-nucleating efficiency of harvest emissions. This was demonstrated by the effect of heating, which greatly reduced INP concentrations for all crops, with the most pronounced effects at warm temperatures. For example, during the wheat harvest, CFDC INP concentrations at $-18^{\circ} \mathrm{C}$ were reduced by $98 \%$ with heat treatment. Post-treatments on the wheat harvest sample indicated the presence of IN active bacteria, mineral dust, and an extraordinarily high proportion of $95^{\circ} \mathrm{C}$ heat-labile (e.g., proteinaceous) INPs. The large contribution of heat-labile material to INPs is unique for the harvest emissions and has not been observed as being so abundant in soil dusts (Hill et al., 2016). A small number of $95^{\circ} \mathrm{C}$ heat-stable organic INPs that were degraded only with peroxide digestion were also observed. Heat-stable organics make up a larger fraction of arable soil dust than were observed here, again suggesting that harvest emissions include plant fragments and other biogenic particles not commonly found in soil dust.

With the ultimate goal of incorporating these data into cloud models, INP parameterizations were used to compare predicted and measured INP concentrations. These comparisons suggested that INP emissions from several crops are complex mixtures of various types of organic, mineral, and biological particles. The inability of the T13 parameterization to predict warm temperature INPs for several crops is due to the low number of FBAPs observed and suggests the presence of unidentified warm temperature INPs that are distinct from the spore-dominated scenario in Tobo et al. (2013). Due to the variety of components that contribute to the INPs, the complexity of the INP spectrum is not accurately modeled by existing INP parameterizations. However, the D10 and D15 parameterizations could be used to give estimates of INPs in agricultural regions. WIBS data can also be used to give estimates of -20 and $-25^{\circ} \mathrm{C}$ INP concentrations using FP3 and FP concentrations, respectively. Corn, soybean, and wheat are the top three most planted crops in the 
United States. Over 2014 and 2015, corn, soybean, wheat, and sorghum crops were planted over $960000 \mathrm{~km}^{2}$ of land in the United States alone (National Agricultural Statistics Service, 2018). The increasing homogenization of crops grown in this part of the US may not have changed the overall number of INPs released compared with the greater heterogeneity of species and strains grown previously. This is because previous crops would have produced a mix of both higher and lower emissions. For example, Georgakopoulos and Sands (1992) recorded a 5000-fold range in populations of IN $P$. syringae among 23 barley lines and cultivars grown in Bozeman, Montana. However, greater patchiness of the landscape would have required a longer period, over which harvesting emissions occurred in each region due to differences in maturation times. In summary, harvest emissions can have a large impact on clouds in agricultural regions and this characterization of harvest-emitted INPs can be used to inform quantitative models using aerosol concentration inputs and will hopefully lead to a better understanding of the role of harvest-emitted INPs in convective clouds in these regions.

Data availability. The data used in this paper are available in a digital library at CSU (https://dspace.library.colostate.edu (last access: 30 March 2018) under the following identifier: https://hdl.handle. net/10217/187173 (last access: 30 March 2018).

\section{The Supplement related to this article is available online at https://doi.org/10.5194/acp-18-13755-2018- supplement.}

Author contributions. KJS collected and analyzed the CFDC, SEM, and WIBS data, organized and planned the field campaigns, and wrote the paper. TCJH collected, ran, and analyzed the IS data, organized and planned the field campaigns, developed with AM the hydrogen peroxide treatment used on the samples, and helped write the paper. EJTL helped collect CFDC and WIBS data and helped write the paper. AM helped develop the hydrogen peroxide treatment used on the samples. PJD conceptualized the study and helped write the paper. SMK helped write the paper.

Competing interests. The authors have no conflict of interest.

Acknowledgements. Funding for this work was provided by NSF grant AGS1358495. Anna Miller was funded by the Reed College Opportunity Fellowship. Special thanks to Norbert Swoboda-Colberg for SEM-EDX analysis and to Larry Howe, Bob Baumgartner, and Kelly Wiseman at SAREC and Freddie Lamm, Dan Foster, and Marv Farmer at the KSU NW Research Center for their help with coordinating the harvest measurements.
Edited by: Allan Bertram

Reviewed by: two anonymous referees

\section{References}

Agresti, A. and Coull, B. A.: Approximate Is Better than "Exact" for Interval Estimation of Binomial Proportions, Am. Stat., 52, 119-126, https://doi.org/10.2307/2685469, 1998.

Albinsson, B., Li, S. M., Lundquist, K., and Stomberg, R.: The origin of lignin fluorescence, J. Mol. Struc., 508, 19-27, 1999.

Augustin, S., Wex, H., Niedermeier, D., Pummer, B., Grothe, H., Hartmann, S., Tomsche, L., Clauss, T., Voigtländer, J., Ignatius, K., and Stratmann, F.: Immersion freezing of birch pollen washing water, Atmos. Chem. Phys., 13, 10989-11003, https://doi.org/10.5194/acp-13-10989-2013, 2013.

Aylor, D. E.: A framework for examining inter-regional aerial transport of fungal spores, Agr. Forest Meteorol., 38, 263-288, doi10.1016/0168-1923(86)90017-1, 1986.

Conen, F., Morris, C. E., Leifeld, J., Yakutin, M. V., and Alewell, C.: Biological residues define the ice nucleation properties of soil dust, Atmos. Chem. Phys., 11, 9643-9648, https://doi.org/10.5194/acp-11-9643-2011, 2011.

Conen, F., Stopelli, E., and Zimmermann, L.: Clues that decaying leaves enrich Arctic air with ice nucleating particles, Atmospheric Environment, 129, 91-94, https://doi.org/10.1016/j.atmosenv.2016.01.027, 2016.

Creamean, J. M., Suski, K. J., Rosenfeld, D., Cazorla, A., DeMott, P. J., Sullivan, R. C., White, A. B., Ralph, F. M., Minnis, P., Comstock, J. M., Tomlinson, J. M., and Prather, K. A.: Dust and Biological Aerosols from the Sahara and Asia Influence Precipitation in the Western U.S., Science, 339, 1572-1578, https://doi.org/10.1126/science.1227279, 2013.

DeMott, P. J., Sassen, K., Poellot, M. R., Baumgardner, D., Rogers, D. C., Brooks, S. D., Prenni, A. J., and Kreidenweis, S. M.: African dust aerosols as atmospheric ice nuclei, Geophys. Res. Lett., 30, 1732, https://doi.org/10.1029/2003GL017410, 2003.

DeMott, P. J., Prenni, A. J., Liu, X., Kreidenweis, S. M., Petters, M. D., Twohy, C. H., Richardson, M. S., Eidhammer, T., and Rogers, D. C.: Predicting global atmospheric ice nuclei distributions and their impacts on climate, P. Natl. Acad. Sci. USA, 107, 1121711222, https://doi.org/10.1073/pnas.0910818107, 2010.

DeMott, P. J., Prenni, A. J., McMeeking, G. R., Sullivan, R. C., Petters, M. D., Tobo, Y., Niemand, M., Moehler, O., Snider, J. R., Wang, Z., and Kreidenweis, S. M.: Integrating laboratory and field data to quantify the immersion freezing ice nucleation activity of mineral dust particles, Atmos. Chem. Phys., 15, 393-409, https://doi.org/10.5194/acp-15-393-2015, 2015.

DeMott, P. J., Hill, T. C. J., McCluskey, C. S., Prather, K. A., Collins, D. B., Sullivan, R. C., Ruppel, M. J., Mason, R. H., Irish, V. E., Lee, T., Hwang, C. Y., Rhee, T. S., Snider, J. R., McMeeking, G. R., Dhaniyala, S., Lewis, E. R., Wentzell, J. J. B., Abbatt, J., Lee, C., Sultana, C. M., Ault, A. P., Axson, J. L., Diaz Martinez, M., Venero, I., Santos-Figueroa, G., Stokes, M. D., Deane, G. B., Mayol-Bracero, O. L., Grassian, V. H., Bertram, T. H., Bertram, A. K., Moffett, B. F., and Franc, G. D.: Sea spray aerosol as a unique source of ice nucleating particles, P. Natl. Acad. Sci. USA, 113, 5797-5803, https://doi.org/10.1073/pnas.1514034112, 2016. 
Eidhammer, T., DeMott, P. J., Prenni, A. J., Petters, M. D., Twohy, C. H., Rogers, D. C., Stith, J., Heymsfield, A., Wang, Z., Pratt, K. A., Prather, K. A., Murphy, S. M., Seinfeld, J. H., Subramanian, R., and Kreidenweis, S. M.: Ice Initiation by Aerosol Particles: Measured and Predicted Ice Nuclei Concentrations versus Measured Ice Crystal Concentrations in an Orographic Wave Cloud, J. Atmos. Sci., 67, 2417-2436, 2010.

FAO Statistical Yearbook - Land Use: available at: http: //www.fao.org/economic/ess/ess-publications/ess-yearbook/ ess-yearbook2010/yearbook2010-reources/en/, (last access: 23 May 2016), 2010.

Flocchini, R. G., James, T. A., Ashbaugh, L. L., Brown, M. S., Carvacho, O. F., Holmen, B. A., Matsumura, R. T., Trzepla-Nabaglo, K., and Tsubamoto, C.: Interim report: Sources and sinks of $\mathrm{PM}_{10}$ in the San Joaquin Valley, Crocker Nuclear Laboratory, UC-Davis, CA, 2001.

Fröhlich-Nowoisky, J., Hill, T. C. J., Pummer, B. G., Yordanova, P., Franc, G. D., and Pöschl, U.: Ice nucleation activity in the widespread soil fungus Mortierella alpina, Biogeosciences, 12, 1057-1071, https://doi.org/10.5194/bg-12-1057-2015, 2015.

Garcia, E., Hill, T. C. J., Prenni, A. J., DeMott, P. J., Franc, G. D., and Kreidenweis, S. M.: Biogenic ice nuclei in boundary layer air over two U.S. High Plains agricultural regions, J. Geophys. Res.Atmos., 117, D18209, https://doi.org/10.1029/2012jd018343, 2012

Georgakopoulos, D. G. and Sands, D. C.: Epiphytic populations of Pseudomonas syringae on barley, Canad. J. Microbiol., 38, 111114, https://doi.org/10.1139/m92-018, 1992.

Govindarajan, A. G. and Lindow, S. E.: Size of bacterial icenucleation sites measured in situ by radiation inactivation analysis, P. Natl. Acad. Sci. USA, 85, 1334-1338, 1988.

Hartmann, S., Augustin, S., Clauss, T., Wex, H., Šantl-Temkiv, T., Voigtländer, J., Niedermeier, D., and Stratmann, F.: Immersion freezing of ice nucleation active protein complexes, Atmos. Chem. Phys., 13, 5751-5766, https://doi.org/10.5194/acp13-5751-2013, 2013.

Hill, T. C. J., Moffett, B. F., DeMott, P. J., Georgakopoulos, D. G., Stump, W. L., and Franc, G. D.: Measurement of Ice Nucleation-Active Bacteria on Plants and in Precipitation by Quantitative PCR, Appl. Environ. Microbiol., 80, 1256-1267, https://doi.org/10.1128/aem.02967-13, 2014.

Hill, T. C. J., DeMott, P. J., Tobo, Y., Fröhlich-Nowoisky, J., Moffett, B. F., Franc, G. D., and Kreidenweis, S. M.: Sources of organic ice nucleating particles in soils, Atmos. Chem. Phys., 16, 7195-7211, https://doi.org/10.5194/acp-16-7195-2016, 2016.

Hiranuma, N., Augustin-Bauditz, S., Bingemer, H., Budke, C., Curtius, J., Danielczok, A., Diehl, K., Dreischmeier, K., Ebert, M., Frank, F., Hoffmann, N., Kandler, K., Kiselev, A., Koop, T., Leisner, T., Moehler, O., Nillius, B., Peckhaus, A., Rose, D., Weinbruch, S., Wex, H., Boose, Y., DeMott, P. J., Hader, J. D., Hill, T. C. J., Kanji, Z. A., Kulkarni, G., Levin, E. J. T., McCluskey, C. S., Murakami, M., Murray, B. J., Niedermeier, D., Petters, M. D., O'Sullivan, D., Saito, A., Schill, G. P., Tajiri, T., Tolbert, M. A., Welti, A., Whale, T. F., Wright, T. P., and Yamashita, K.: A comprehensive laboratory study on the immersion freezing behavior of illite NX particles: a comparison of 17 ice nucleation measurement techniques, Atmos. Chem. Phys., 15, 2489-2518, https://doi.org/10.5194/acp-15-2489-2015, 2015.
Huffman, J. A., Prenni, A. J., DeMott, P. J., Pöhlker, C., Mason, R. H., Robinson, N. H., Fröhlich-Nowoisky, J., Tobo, Y., Després, V. R., Garcia, E., Gochis, D. J., Harris, E., MüllerGermann, I., Ruzene, C., Schmer, B., Sinha, B., Day, D. A., Andreae, M. O., Jimenez, J. L., Gallagher, M., Kreidenweis, S. M., Bertram, A. K., and Pöschl, U.: High concentrations of biological aerosol particles and ice nuclei during and after rain, Atmos. Chem. Phys., 13, 6151-6164, https://doi.org/10.5194/acp13-6151-2013, 2013.

Igel, A. L., van den Heever, S. C., Naud, C. M., Saleeby, S. M., and Posselt, D. J.: Sensitivity of Warm-Frontal Processes to CloudNucleating Aerosol Concentrations, J. Atmos. Sci., 70, 1768 1783, https://doi.org/10.1175/JAS-D-12-0170.1, 2013.

IPCC: Summary for Policymakers. In: Climate Change 2013: The Physical Science Basis, Contribution of Working Group I to the Fifth Assessment Report of the Intergovernmental Panel on Climate Change, Cambridge, United Kingdom and New York, NY, USA, 1-30, 2013.

Kreidenweis, S. M., Chen, Y., Rogers, D. C., and DeMott, P. J.: Isolating and identifying atmospheric ice-nucleating aerosols: a new technique, Atmos. Res., 46, 263-278, https://doi.org/10.1016/S0169-8095(97)00068-9, 1998.

Li, Z., Niu, F., Fan, J., Liu, Y., Rosenfeld, D., and Ding, Y.: Long-term impacts of aerosols on the vertical development of clouds and precipitation, Nature Geosci., 4, 888-894, available at: http://www.nature.com/ngeo/journal/ v4/n12/abs/ngeo1313.html\#supplementary-information (last access: 30 March 2018), 2011.

Lighthart, B.: Microbial Aerosols: Estimated Contribution of Combine Harvesting to an Airshed, Appl. Environ. Microbiol., 47, 430-432, 1984.

Lux, A., Luxova, M., Hattori, T., Inanaga, S., and Sugimoto, Y.: Silicification in sorghum (Sorghum bicolor) cultivars with different drought tolerance, Physiol. Plantarum, 115, 87-92, https://doi.org/10.1034/j.1399-3054.2002.1150110.x, 2002.

Mason, R. H., Si, M., Chou, C., Irish, V. E., Dickie, R., Elizondo, P., Wong, R., Brintnell, M., Elsasser, M., Lassar, W. M., Pierce, K. M., Leaitch, W. R., MacDonald, A. M., Platt, A., ToomSauntry, D., Sarda-Estève, R., Schiller, C. L., Suski, K. J., Hill, T. C. J., Abbatt, J. P. D., Huffman, J. A., DeMott, P. J., and Bertram, A. K.: Size-resolved measurements of ice-nucleating particles at six locations in North America and one in Europe, Atmos. Chem. Phys., 16, 1637-1651, https://doi.org/10.5194/acp16-1637-2016, 2016.

McCluskey, C. S., DeMott, P. J., Prenni, A. J., Levin, E. J. T., McMeeking, G. R., Sullivan, A. P., Hill, T. C. J., Nakao, S., Carrico, C. M., and Kreidenweis, S. M.: Characteristics of atmospheric ice nucleating particles associated with biomass burning in the US: Prescribed burns and wildfires, J. Geophys. Res.-Atmos., 119, 10458-10470, https://doi.org/10.1002/2014jd021980, 2014.

McCluskey, C. S., Hill, T. C., Sultana, C. M., Laskina, O., Trueblood, J., Santander, M. V., Beall, C. M., Michaud, J. M., Kreidenweis, S. M., Prather, K. A., Grassian, V., and DeMott, P. J.: A Mesocosm Double Feature: Insights into the Chemical Makeup of Marine Ice Nucleating Particles, J. Atmos. Sci., 75, 24052423, https://doi.org/10.1175/JAS-D-17-0155.1, 2018.

Morris, C. E., Sands, D. C., Glaux, C., Samsatly, J., Asaad, S., Moukahel, A. R., Gonçalves, F. L. T., and Bigg, E. K.: Ure- 
diospores of rust fungi are ice nucleation active at $>-10{ }^{\circ} \mathrm{C}$ and harbor ice nucleation active bacteria, Atmos. Chem. Phys., 13, 4223-4233, https://doi.org/10.5194/acp-13-4223-2013, 2013.

Nagarajan, S. and Singh, D. V.: Long-Distance Dispersion of Rust Pathogens, Ann. Rev. Phytopathol., 28, 139-153, https://doi.org/10.1146/annurev.py.28.090190.001035, 1990.

National Agricultural Statistics Service, Agricultural Statistics Board, United States Department of Agriculture (USDA), https: //www.nass.usda.gov/, last access: 29 January 2018.

O’Sullivan, D., Murray, B. J., Malkin, T. L., Whale, T. F., Umo, N. S., Atkinson, J. D., Price, H. C., Baustian, K. J., Browse, J., and Webb, M. E.: Ice nucleation by fertile soil dusts: relative importance of mineral and biogenic components, Atmos. Chem. Phys., 14, 1853-1867, https://doi.org/10.5194/acp-141853-2014, 2014.

O'Sullivan, D., Murray, B. J., Ross, J. F., and Webb, M. E.: The adsorption of fungal ice-nucleating proteins on mineral dusts: a terrestrial reservoir of atmospheric ice-nucleating particles, Atmos. Chem. Phys., 16, 7879-7887, https://doi.org/10.5194/acp16-7879-2016, 2016.

Petters, M. D. and Wright, T. P.: Revisiting ice nucleation from precipitation samples, Geophys. Res. Lett., 42, 8758-8766, https://doi.org/10.1002/2015GL065733, 2015.

Pratt, K. A., DeMott, P. J., French, J. R., Wang, Z., Westphal, D. L., Heymsfield, A. J., Twohy, C. H., Prenni, A. J., and Prather, K. A.: In situ detection of biological particles in cloud ice-crystals, Nature Geosci., 2, 398-401, http://www.nature.com/ngeo/journal/ v2/n6/suppinfo/ngeo521_S1.html, 2009.

Prenni, A. J., DeMott, P. J., Sullivan, A. P., Sullivan, R. C., Kreidenweis, S. M., and Rogers, D. C.: Biomass burning as a potential source for atmospheric ice nuclei: Western wildfires and prescribed burns, Geophys. Res. Lett., 39, L11805, https://doi.org/10.1029/2012GL051915, 2012.

Prenni, A. J., Tobo, Y., Garcia, E., DeMott, P. J., Huffman, J. A., McCluskey, C. S., Kreidenweis, S. M., Prenni, J. E., Poehlker, C., and Poeschl, U.: The impact of rain on ice nuclei populations at a forested site in Colorado, Geophys. Res. Lett., 40, 227-231, https://doi.org/10.1029/2012g1053953, 2013.

Pummer, B. G., Bauer, H., Bernardi, J., Bleicher, S., and Grothe, H.: Suspendable macromolecules are responsible for ice nucleation activity of birch and conifer pollen, Atmos. Chem. Phys., 12, 2541-2550, https://doi.org/10.5194/acp-12-2541-2012, 2012.

Rogers, D. C., DeMott, P. J., Kreidenweis, S. M., and Chen, Y. L.: A continuous-flow diffusion chamber for airborne measurements of ice nuclei, J. Atmos. Ocean. Technol., 18, 725-741, 2001.

Romay, F. J., Roberts, D. L., Marple, V. A., Liu, B. Y. H., and Olson, B. A.: A High-Performance Aerosol Concentrator for Biological Agent Detection, Aerosol Sci. Technol., 36, 217-226, https://doi.org/10.1080/027868202753504074, 2002.

Roy, R. N. and Wright, B. C.: Sorghum Growth and Nutrient Uptake in Relation to Soil Fertility, II. N, P, and K Uptake Pattern by Various Plant Parts1, Agronomy J., 66, 5-10, https://doi.org/10.2134/agronj1974.00021962006600010002x, 1974.

Saide, P. E., Spak, S. N., Pierce, R. B., Otkin, J. A., Schaack, T. K., Heidinger, A. K., da Silva, A. M., Kacenelenbogen, M., Redemann, J., and Carmichael, G. R.: Central American biomass burning smoke can increase tornado severity in the U.S., Geophys. Res. Lett., 42, 956-965, https://doi.org/10.1002/2014GL062826, 2015.

Schill, G. P., Jathar, S. H., Kodros, J. K., Levin, E. J. T., Galang, A. M., Friedman, B., Link, M. F., Farmer, D. K., Pierce, J. R., Kreidenweis, S. M., and DeMott, P. J.: Ice-nucleating particle emissions from photochemically aged diesel and biodiesel exhaust, Geophys. Res. Lett., 43, 5524-5531, 2016.

Schnell, R. C. and Vali, G.: Biogenic Ice Nuclei: Part I. Terrestrial and Marine Sources, J. Atmos. Sci., 33, 1554-1564, https://doi.org/10.1175/15200469(1976)033<1554:BINPIT>2.0.CO;2, 1976.

Seigel, R. B., van den Heever, S. C., and Saleeby, S. M.: Mineral dust indirect effects and cloud radiative feedbacks of a simulated idealized nocturnal squall line, Atmos. Chem. Phys., 13, 44674485, https://doi.org/10.5194/acp-13-4467-2013, 2013.

Tobo, Y., Prenni, A. J., DeMott, P. J., Huffman, J. A., McCluskey, C. S., Tian, G., Poehlker, C., Pöschl, U., and Kreidenweis, S. M.: Biological aerosol particles as a key determinant of ice nuclei populations in a forest ecosystem, J. Geophys. Res.-Atmos., 118, 10100-10110, https://doi.org/10.1002/jgrd.50801, 2013.

Tobo, Y., DeMott, P. J., Hill, T. C. J., Prenni, A. J., SwobodaColberg, N. G., Franc, G. D., and Kreidenweis, S. M.: Organic matter matters for ice nuclei of agricultural soil origin, Atmos. Chem. Phys., 14, 8521-8531, https://doi.org/10.5194/acp14-8521-2014, 2014.

Vali, G.: Quantitative Evaluation of Experimental Results an the Heterogeneous Freezing Nucleation of Supercooled Liquids, J. Atmos. Sci., 28, 402-409, https://doi.org/10.1175/15200469(1971)028<0402:QEOERA>2.0.CO; 2, 1971.

Wang, J., van den Heever, S., C., and Reid, J. S.: A conceptual model for the link between Central American biomass burning aerosols and severe weather over the south central United States, Environ. Res. Lett., 4, 015003, https://doi.org/10.1088/17489326/4/1/015003, 2009.

Wilson, T. W., Ladino, L. A., Alpert, P. A., Breckels, M. N., Brooks, I. M., Browse, J., Burrows, S. M., Carslaw, K. S., Huffman, J. A., Judd, C., Kilthau, W. P., Mason, R. H., McFiggans, G., Miller, L. A., Najera, J. J., Polishchuk, E., Rae, S., Schiller, C. L., Si, M., Temprado, J. V., Whale, T. F., Wong, J. P. S., Wurl, O., Yakobi-Hancock, J. D., Abbatt, J. P. D., Aller, J. Y., Bertram, A. K., Knopf, D. A., and Murray, B. J.: A marine biogenic source of atmospheric ice-nucleating particles, Nature, 525, 234-238, https://doi.org/10.1038/nature14986, 2015.

Wright, T. P. and Petters, M. D.: The role of time in heterogeneous freezing nucleation, J. Geophys. Res.-Atmos., 118, 3731-3743, https://doi.org/10.1002/jgrd.50365, 2013.

Wright, T. P., Hader, J. D., McMeeking, G. R., and Petters, M. D.: High Relative Humidity as a Trigger for Widespread Release of Ice Nuclei, Aerosol Sci. Technol., 48, i-v, https://doi.org/10.1080/02786826.2014.968244, 2014. 